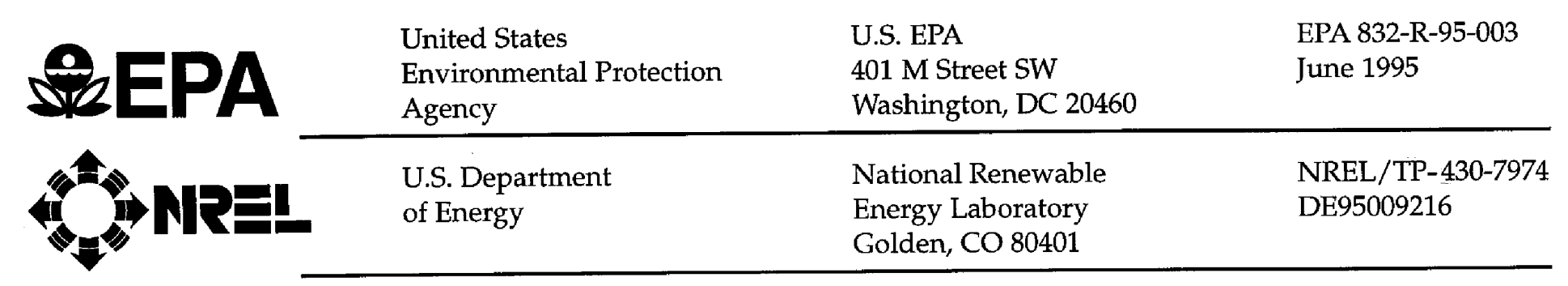

\title{
Case Studies in Residual Use and Energy Conservation at Wastewater Treatment Plants
}

\author{
Interagency \\ Energy and Environmental \\ Research Report
}

U.S. Environmental Protection Agency

Office of Wastewater Management

Washington, DC

U.S. Department of Energy Energy Efficiency, Conservation and Renewable Energy Washington, DC 


\section{NOTICE}

This report was prepared as an account of work sponsored by an agency of the United States government. Neither the United States government nor any agency thereof, nor any of their employees, makes any warranty, express or implied, or assumes any legal liability or responsibility for the accuracy, completeness, or usefulness of any information, apparatus, product, or process disclosed, or represents that its use would not infringe privately owned rights. Reference herein to any specific commercial product, process, or service by trade name, trademark, manufacturer, or otherwise does not necessarily constitute or imply its endorsement, recommendation, or favoring by the United States government or any agency thereof. The views and opinions of authors expressed herein do not necessarily state or reflect those of the United States government or any agency thereof.

Available to DOE and DOE contractors from:

Office of Scientific and Technical Information (OSTI)

P.O. Box 62

Oak Ridge, TN 37831

Prices available by calling (615) 576-8401

Available to the public from:

National Technical Information Service (NTIS)

U.S. Department of Commerce

5285 Port Royal Road

Springfield, VA 22161

(703) $487-4650$ 


\section{EPA Review Notice}

This report has been reviewed by the U.S. Environmental Protection Agency, and approved for publication. Approval does not signify that the contents necessarily reflect the views and policy of the agency, nor does mention of trade names or commercial products constitute endorsement or recommendation for use.

This document is available to the public through the National Technical Information Service, Springfield, Virginia 22161. 


\section{CONTENTS}

Acknowledgements $\ldots \ldots \ldots \ldots \ldots \ldots \ldots \ldots \ldots \ldots \ldots \ldots \ldots \ldots \ldots \ldots \ldots \ldots$ iii

Forward $. . \ldots \ldots \ldots \ldots \ldots \ldots \ldots \ldots \ldots \ldots \ldots \ldots \ldots \ldots \ldots \ldots \ldots, v$

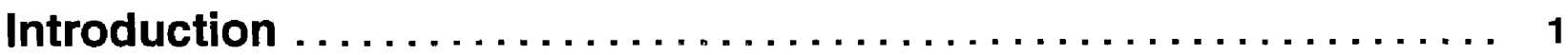

Background * Basics of Biogas Generation and Use * In-Plant Applications for Biogas * Precautions for Use of Unscrubbed Biogas

County Sanitation Districts of Orange County .............. 9

Facility Description * Description of the Technologies * Process Modifications * Pretreatment Program Effects on Energy Conservation * Benefits of the Energy Conservation Program

City of Los Angeles Hyperion Wastewater Treatment Plant ....... 17

Facility Description * Energy Recovery from Biogas * Energy Recovery from Biosolids * Process Modifications * Benefits of the Energy Conservation Program

Sunnyvale Water Pollution Control Plant

Facility Description * Description of the Technologies * Operation and Maintenance * Landfill Gas Production * Biosolids Dewatering

Sanford Big Buffalo Creek WWTP, North Carolina ............

Facility Description * Energy Conservation Audit * Description of the Technologies * Process Modifications * Financial Benefits

Seattle Metro Renton Water Reclamation Plant . .

Facility Description * Energy Recovery from Biogas * The Metro Therm Program * Applicability to Other Systems * Benefits of the Energy Conservation Program

Other Promising Technologies 53

Anaerobic Wastewater Treatment * Lake County Southeast Geysers Effluent

Pipeline * Biomass-Enhanced Digester Gas Production

Factors that Contribute to Success 
The Influence of Financial Factors $\ldots \ldots \ldots \ldots \ldots \ldots \ldots \ldots \ldots \ldots$ Biosolids: Onsite Use versus Offsite Reuse * Biogas: Onsite Use versus Offsite Sale * Energy from Effluent: Purchase versus Contractual Equipment

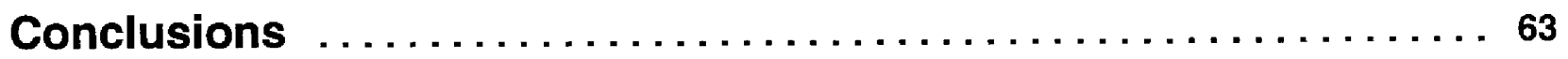

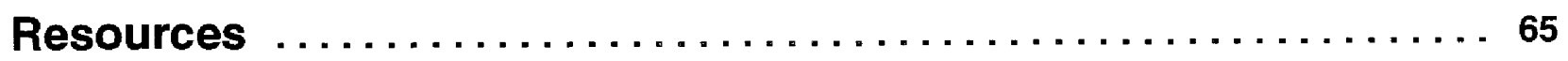




\section{Acknowledgements}

This report was prepared by Science Applications International Corporation under National Renewable Energy Laboratory Subcontract No. YAE-3-13480-01 for the U.S. Department of Energy, and Contract No. 68-C8-0066, WA No. C-4-73 (M) with the U.S.

Environmental Protection Agency.

We thank the staff and management of each of the wastewater treatment plants involved in this study for cheerfully providing information and graphics. 


\section{Foreword}

$\mathbf{P}$

ublic support for water quality improvement has placed increasing demands on wastewater treatment plants in the years since passage of the Clean Water Act in 1972. The public's expectations and the resulting new environmental legislation (at national, state, and local levels) have led to new programs and increased expenditures.

As a result, WWTP managers continually tackle issues associated with broadening environmental concerns. These concerns include aquatic habitat protection, wastewater reclamation, air quality issues, industrial waste disposal, biosolids reuse, and others up to and including global climate change. Many plant managers are dealing with all these issues and the corollary need for funding.

The premise of this document is that WWTPs can address environmental mandates in an integrated framework based on energy conservation, through the use of renewable resources. As the examples presented herein show, activities that conserve energy also reduce pollution and costs. Energy conservation is a particularly appropriate goal for WWTPs, which exist to reduce pollution.

WWTPs are among the few community institutions that are efficiently designed to manage renewable resources.

Conventionally, renewable resources are considered to include water, air and soil, wild and domesticated organisms, forests, rangelands, cultivated land, marine and freshwater ecosystems that support fisheries, and other aspects of the natural environment. However, human ability to manage these scattered and generally poorly understood resources is in most respects very limited. In contrast, WWTPs have collection systems to convey the resource to a single point. Treatment processes then separate solids from the water fraction, producing different resource streams for reuse.

Many plants now profitably obtain methane for in-plant energy production from the biosolids fraction. Examples of such facilities are discussed in this document. However, some plants are moving forward to generate energy from a combination of landfill gas and digester gas (as seen in Sunnyvale, CA) or production of digester gas for offsite sale (Seattle Metro), or biosolids oxidation to produce energy for onsite and offsite uses (Los Angeles' Hyperion plant). Creative WWTPs are also solving community waste disposal problems by placing highstrength biowastes into anaerobic digesters. These facilities benefit from the resulting increased production of methane.

Energy can also be obtained from wastewater effluent, as demonstrated by Seattle Metro and The Boeing Company. By using Seattle Metro's effluent for cooling via heat exchangers, instead of building cooling towers, Boeing has conserved potable water and preserved the City viewscape. Any WWTP faced with building pipelines for water reclamation purposes can explore this use of effluent. The potential for energy 
conservation by using effluent in heat exchangers is enormous; the U.S.

Department of Energy has estimated that space heating and cooling account for 34 percent of commercial energy usage and 46 percent of residential usage. Great community benefit would be obtained even if only a small part of this usage were defrayed.
By integrating wastewater treatment with energy conservation, the WWTPs described in this document have met the challenges of new environmental regulations. These facilities have achieved benefits in cost savings while enhancing their ability to comply with regulations. Their activities illustrate highly effective pollution prevention strategies. 


\section{Introduction}

$\mathbf{T}$

he U.S. Environmental

Protection Agency (EPA) and

the National Renewable

Energy Laboratory (NREL) for the

U.S. Department of Energy (DOE)

funded a study to document energy

conservation activities and their effects

on operation costs, regulatory

compliance, and process optimization

at several wastewater treatment plants

(WWTPs).

The purpose of this report is to review the efforts of wastewater treatment facilities that use residuals as fuels. Case histories are presented for facilities that have taken measures to reduce energy consumption during wastewater treatment. Most of the WWTPs discussed in this report have retrofitted existing facilities to achieve energy conservation. The case studies of energy conservation measures found no effects on the facilities' ability to comply with NPDES permits. Indeed, energy conservation activities enhance environmental compliance in several ways.

\section{Background}

Studies conducted previously by DOE identified the wastewater treatment processes with the highest energy usage. These processes exhibit the greatest potential for energy savings, and include activated sludge, biosolids dewatering and
Beginning in the mid-1970's, industry and government has perceived an increasing need for energy conservation efforts. While water conservation has long been a goal, recent initiatives requiring municipal pollution prevention programs support the need to seek innovative solutions that address both concerns in a holistic manner. conditioning, biosolids incineration, aerobic digestion, advanced wastewater treatment, and use of aeration ponds. Anaerobic digestion uses comparatively small amounts of energy, but also shows great potential for energy savings because its energy requirements are easily reduced through the use of biogas for heating, the technology to do so is commercially available, and the economics is almost always favorable.

A survey conducted by the Illinois Association of Wastewater Agencies found that the annual energy costs for wastewater treatment plants in Illinois ranged from 20 to 35 percent of 1990 operation and maintenance (O\&M) costs. In comparison to this figure, the County Sanitation Districts of Orange County, which has implemented a comprehensive energy conservation program, expects to spend only 6 percent of its total O\&M budget on energy during fiscal year 1993-94. 
The DOE studies found that WWTP managers' primary concern is to meet discharge requirements. Energy conservation, when considered at all, is often of secondary importance. Now, many WWTP managers are finding that energy conservation and use of residuals as fuels can actually enhance environmental compliance. The experiences of some of these facilities are presented as examples to other agencies considering whether to implement such technologies.

\section{Basics of Biogas Generation and Use}

Anaerobic digestion is one of the most widely used processes of wastewater biosolids stabilization. The process involves bacterial decomposition of the organic constituents of the biosolids in the absence of oxygen. The products of anaerobic digestion, apart from solids, include water and a gas composed of methane, carbon dioxide, hydrogen sulfide, and other minor gaseous compounds. This "biogas" has a heat value of approximately $550 \mathrm{Btu} / \mathrm{tt}^{3}$, about 60 percent of the heat value of natural gas.

Biogas may be used either off-site or within the plant to improve energy efficiency of wastewater treatment processes. Both possibilities should be considered when designing new treatment facilities or upgrading existing ones.
Local objectives and conditions, however, will decide the use made of biogas at a particular plant.

In-plant uses are those that result in the biogas being consumed completely within the wastewater treatment plant, either as primary or backup fuel. Uses include fueling boilers in process heating operations and space heating and cooling, engine-driven machinery, engine generators for electricity generation, solids incinerators, boilers for pasteurization of digested biosolids, gas fired biosolids dryers, and generation of electricity by steam turbines and fuel cells. Figure 1 provides a schematic of in-plant uses. These uses are described in detail in the next section.

Use of waste heat recovery increases energy efficiency in the system, and is of particular value whenever in-plant use involves the operation of equipment not primarily designed to produce heat (i.e., engines, incinerators, turbines, etc.). As the case histories in this study demonstrate, fuel energy efficiency can be increased from 30 to 70 percent by recovering heat for process or space heating/cooling requirements. Recovery of biogas should always be supplemented with waste gas burners, or flares, to ensure that excess gas is controlled with the smallest environmental impact. 
Residuals Use and Energy Conservation

Offsite, biogas can be used to create either energy or chemicals that are sold for use external to the plant. There are many potential offsite uses for biogas, as indicated in the schematic in Figure 2.
The case study presented below of Seattle Metro's Renton Reclamation Plant describes one such use. Generally, it is less practical to process biogas for offsite uses if the gas can be used in the plant.

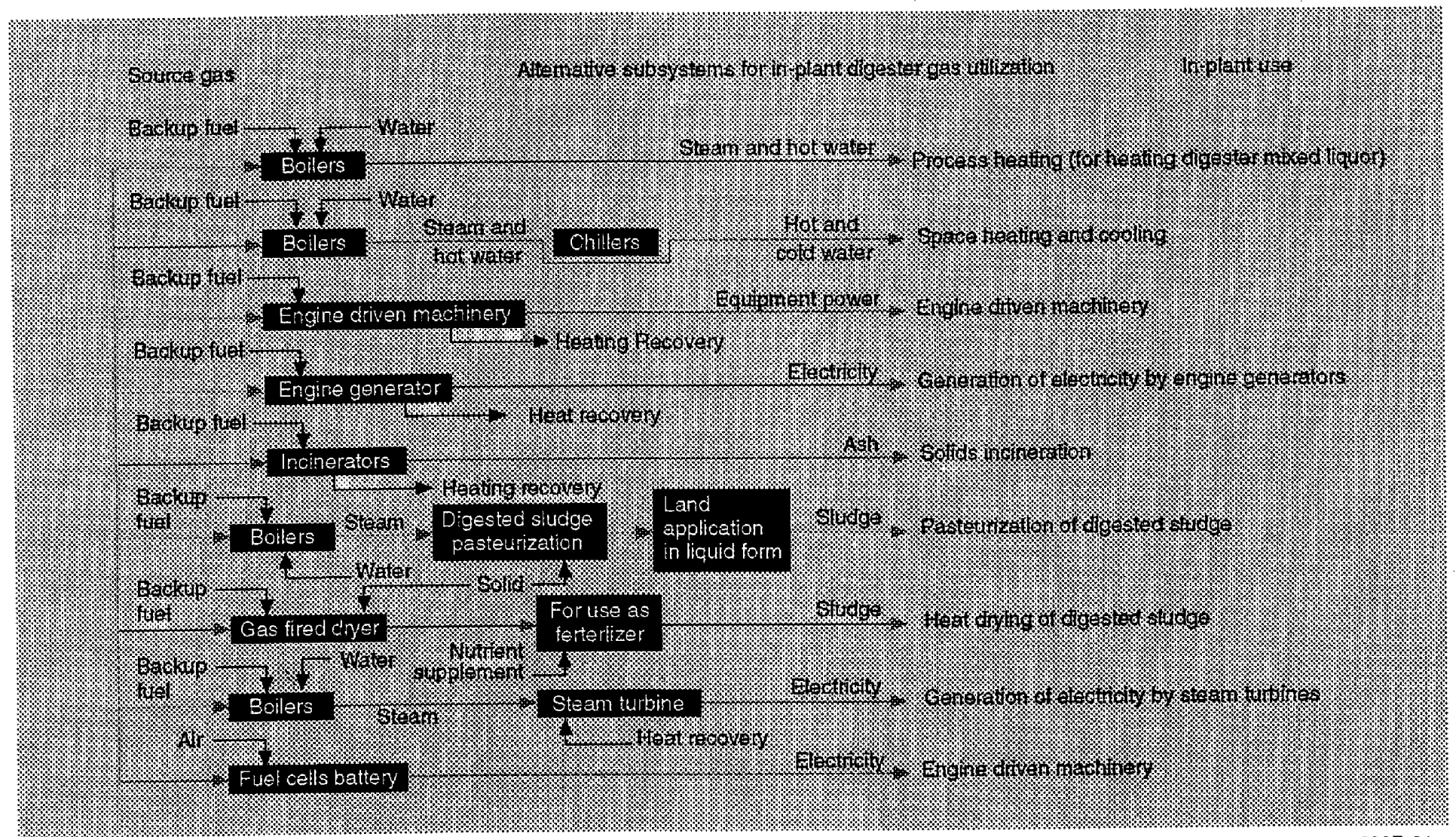

$606 \mathrm{~B}-21$

Figure 1: Onsite uses for biogas 


\section{In-Plant Applications for Biogas}

Biogas use can result in significant energy savings. Production depends on plant wastewater flows and suspended solids loading, rather than on warm weather or other outside variables, as long as the digester environment is uniform.

The five most adaptable in-plant uses for biogas are as a fuel for (1) generating heat for treatment processes, (2) generating heat for space heating and cooling, (3) powering engines used to drive equipment directly, (4) powering engines used with generators to drive remote equipment, and (5) powering engines used with generators to produce general purpose electrical power.

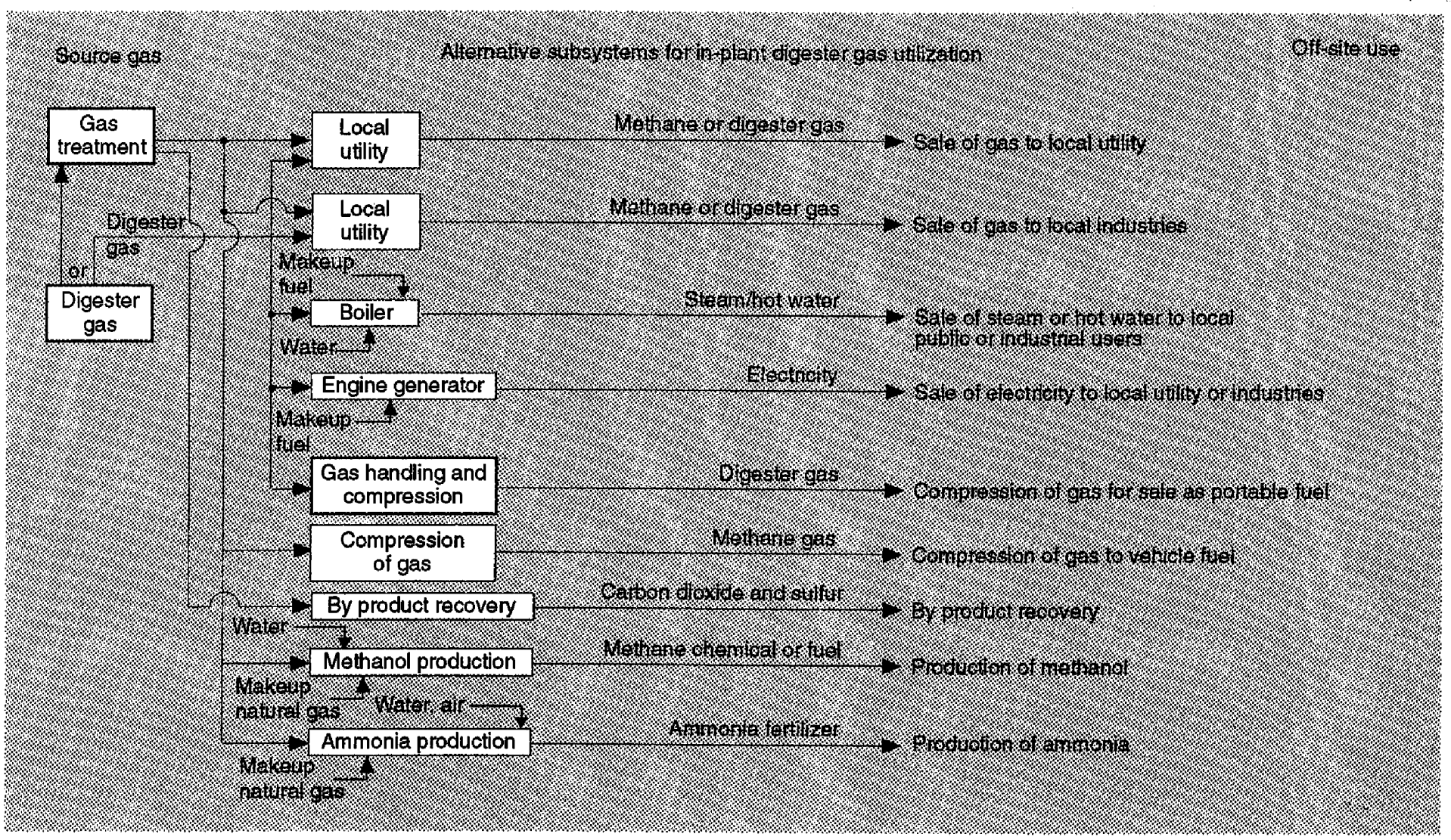

Figure 2: Offsite uses for biogas 


\section{Process Heating}

A plant that uses anaerobic digestion for biosolids stabilization should include a process-heating system that can maintain the contents of the digesters at their optimum temperature (usually $95^{\circ} \mathrm{F}$ ). Such a system should maintain boiler temperatures above $212^{\circ} \mathrm{F}$, and hot water in the biosolids heat exchanger should not be allowed to rise above $160^{\circ} \mathrm{F}$. At temperatures more than $160^{\circ} \mathrm{F}$ the biosolids heat exchanger may cake with biosolids, which quickly ruins the system's heat transfer coefficient. Other uses of process heat include chlorine and sulfur dioxide evaporation and raw biosolids and scum preheating.

\section{Space Heating}

The use of space heating can be expanded effectively to include space cooling. When combined with absorptive refrigeration units, the hot water produced with the biogas can be arranged to produce chilled water, which can then be piped around the plant for space and equipment cooling. Often such space cooling can increase savings by eliminating the need for excessive ventilation.

\section{Direct Engine Drives}

Direct engine-driven equipment usually is employed in plants whose major horsepower demands are required only during peak flow or load conditions, for example, raw wastewater pumps, effluent pumps, and aeration blowers. The use of direct engine-driven equipment eliminates the need for standby electric power to operate this equipment during periods of peak load. The electric power company, in turn, can make this peaking power available to someone else. Any type of treatment plant can use direct enginedriven equipment.

\section{Indirect Engine Drives}

Indirect engine-driven equipment provides the designer with an exceptionally flexible system. It can be used (1) to reduce peak demands of major equipment that is remote from the source of fuel and maintenance, (2) to drive both local and remote equipment, (3) to achieve operational speed variability of remote major equipment, and (4) to use engine generators as both indirect engine drivers and general-purpose electrical generators. The extra flexibility obtained by using indirect engine-driven equipment may be the difference between efficient and inefficient use of biogas.

\section{General Purpose Power Generation}

As more plants are modified or enlarged to include secondary treatment processes, efficient use of biogas will require greater use of in-plant, general-purpose power generation. Biogas production from plants involving secondary treatment can be sufficient to provide up to 60 to 80 percent of the plant's total power needs, depending on the actual treatment processes involved. In those plants with minimal process pumping, biogas may provide nearly all of the power needs. Engines for generating plant power usually operate at slower speeds and 
lower mean effective pressures. Such heavy-duty engines can generate power reliably for many years.

\section{Precautions for Use of Unscrubbed Biogas}

Biogas contains 60 to 70 percent methane, 30 to 40 percent carbon dioxide, up to $1 / 2$ percent hydrogen sulfide and other inert gases and water vapor. Many WWTPs clean up the biogas before use to remove contaminants. Sunnyvale, for instance, uses simple baffle plate condensers to remove moisture from biogas. Biogas from Hyperion's anaerobic digesters contains 60 to 100 ppm of hydrogen sulfide, which would produce unacceptable emissions when the gas is burned. Therefore, Hyperion treats the biogas in a Stretford unit to reduce the sulfur content to less than $40 \mathrm{ppm}$ of hydrogen sulfide. Seattle Metro removes carbon dioxide from biogas produced at the Renton WWTP before sale to the local gas utility for offsite use. Biogas which does not meet the standard of 99 percent purity is rejected by the utility.

Depending on local factors and the final use intended for the biogas, scrubbing is not always necessary. However, certain precautions should be considered in the event that biogas is used without scrubbing. Any boiler or engine using unscrubbed biogas must be operated at temperatures above $212^{\circ} \mathrm{F}$. Unless the combustion temperature is maintained at a high level, exhaust temperatures will not be sufficient to maintain non-condensing conditions within the collection and discharge conduits. The carbon dioxide and hydrogen sulfide in the spent biogas becomes acidic and extremely corrosive when combined with water. Exhaust condensation must be eliminated from equipment fueled by unscrubbed biogas. Blending biogas with a gas having lower hydrogen sulfide content can reduce the corrosivity concerns associated with unscrubbed biogas.

Biogas heat recovery systems must be isolated from each other. The upsets (production rate changes) of one system must never be allowed to affect the operation of another. This isolation can best be accomplished by using separate steam condensers to transfer the boiler or engine heat into a common hot-watercirculation system. The system provides a flexible method of transferring heat throughout the plant. Using individual secondary parallel heat loops to points of need assures that the final supply of hot water is at optimum temperature. 


\section{County Sanitation Districts of Orange County}

This section discusses the energy programs implemented at the two wastewater treatment plants operated by the County Sanitation Districts of Orange County.

\section{Facility Description}

The County Sanitation Districts of Orange County (CSDOC) provides wastewater treatment for a population of about 2.1 million people. CSDOC operates two treatment plants, with a combined average wastewater flow of about 235 MGD. Each plant uses advanced primary treatment with ferric chloride and anionic polymer addition in the primary basins. About 50 percent of the plants' flow receives secondary treatment. The plants discharge to the ocean through a common outfall which has a 301(h) waiver.

CSDOC has carried out various energy conservation techniques for several years. For instance, the facility uses biogas to heat the digesters and to fuel some engines that run pumps and blowers. However, the recovery system did not have the capacity to use all the gas produced by the digesters, and the excess was burned off. In 1989, CSDOC codified formal energy conservation plans in the "2020 Vision Plan."
The 2020 Vision Plan incorporates a variety of energy conservation activities, including lighting, building heating and cooling, and generation of electricity onsite.

In June 1993 CSDOC put the Central Power Generation System (Central Gen) on-line. Central Gen incorporates stateof-the-art techniques to reclaim energy from biogas. This system has been installed at both treatment plants. Currently, CSDOC does not purchase any electricity, as all of its electricity needs are supplied by onsite manufacture of energy from a combination of biogas and natural gas. CSDOC projects that by the year 2010 enough biogas will be produced to completely fuel all the generators.

Other aspects of CSDOC's energy conservation program include improving operator skills, motivating and training operators to be "energy aware," providing computerized power management data, optimizing equipment for maximum efficiency, and providing management technical skills, support, and funding. CSDOC has an energy conservation committee to review existing measures and propose new possibilities for savings. Operation of processes at the treatment plants is aggressive. CSDOC has implemented a lighting conservation program and a summer peak savings program. 
Description of the Technologies: Central Power Generation System

Central Gen consists of a total of eight internal combustion engines fueled by both biogas and natural gas. The engines drive generators to produce electricity that is then used to operate the treatment plants. These engines were specifically designed to reduce emissions from the engine exhaust and to use all the gas produced by the digesters. Power output is 5 megawatts at the Fountain Valley plant (Plant 1) and 7 megawatts at the Huntington Beach plant (Plant 2).

Plant 2 has the greater energy demand (8 megawatts), due mainly to the presence of the outfall pumping station at this plant. Plant 1 uses about 4 megawatts. Now, all biogas from Plant 1 is exported via pipeline to Plant 2 for use, and the Plant 1 Central Gen operates entirely on natural gas.

The three engine generators installed at CSDOC's Plant 1 are Cooper Bessemer Model LSVB-12SGC. The five engine generators installed at CSDOC's Plant 2 are Cooper Bessemer Model LSVB16SGC. Plant 1 engines are rated at 2,500 kilowatts each, and those at Plant 2 are rated at 3,000 kilowatts. At 7,200 Btu/horsepower, the engines are highly efficient.

The engine units consist of an electrical generator, a spark ignition gas-fueled internal combustion engine, engine cooling equipment with automatic and manual controls, and engine exhaust and jacket water heat recovery equipment and controls. All engines are the stratified combustion charge type, with separate precombustion chambers designed to reduce exhaust pollutant emissions. The generators' design efficiency is rated at a minimum of 96.5 percent at rated conditions.

Each engine has a fuel-injection system suitable for accommodating biogas and natural gas. A fuel gas cutoff valve and totalizing flowmeter are provided for both fuels and each engine. The engines can use either biogas, natural gas, or any combination of the two fuel types. The engine fuel control system can rapidly and automatically adjust the fuel/air ratio in response to changes in engine load or fuel heating value. The engine design enables the fuel control system to accomplish these adjustments in a manner that does not reduce engine efficiency or result in greater pollutant emissions, even at a fuel value fluctuation rate of up to plus or minus 100 Btu per cubic foot per minute.

Three-stage biogas filters to remove oil, water mist, and solids are installed on the engine fuel supply piping. The three stages consist of: (1) mechanical centrifugal separation, (2) separation by coalescing and entrainment, and (3) final filtration through a porous-fiberglass medium. These filters are designed to remove 99 percent of all dispersed liquid, five microns and larger, and a minimum of 98 percent of all solids, one micron and larger. A differential pressure gauge is present to indicate when cleaning or replacement of the filters is necessary. 
Each engine generator unit has an electronic governing system for automatic synchronization, load sharing, and load regulation. An air fuel ratio controller is also present on each engine to continuously monitor the air fuel ratio. Systems that use exhaust sensors can be susceptible to damage by components of biogas, so CSDOC specified that control of the air fuel ratio must be maintained by monitoring air manifold temperature and pressure and engine load instead. Engines are also supplied with various protective and safety devices and monitoring and measuring devices to ensure safe and efficient operation. Equipment vendors and a consulting firm provided operator training for Central Gen.

\section{Description of the Technologies: Waste Heat Recovery}

The facility uses engine heat to heat the digesters and for some heating and cooling needs of buildings. The ability to recover and use "waste" heat gives Central Gen greater thermal efficiency than that of Southern California Edison (60\% compared to $30 \%$ ). Each engine generator has a minimum recoverable thermal output at rated load as follows:

\begin{tabular}{|c|c|c|}
\hline Sounces & : & (1: \\
\hline Engine exhaust & 4.39 & 5.27 \\
\hline Engine jacket water & 1.90 & 2.30 \\
\hline Total & 6.29 & 7.57 \\
\hline
\end{tabular}

The jacket water heat recovery system transfers heat to a plant-wide circulating pressurized hot water system. The exhaust heat recovery system is designed to reduce the engine exhaust gas temperature to a minimum of $380^{\circ} \mathrm{F}$ while generating 125 psig dry saturated steam.

\section{Process Modifications: Advanced Primary Treatment}

Application of advanced primary treatment (APT) at both plants has increased solids and BOD removal in the primaries. This resulted in an increase in biogas production, because the energy content of the solids recovered from the primaries is greater than that for solids recovered from secondary treatment. In APT, chemicals are added to the primary settling facilities. Currently, ferric chloride and polymer are added for about 12 to 13 hours daily. The facility has conducted experiments with chemical addition on a continuous 24-hour per day basis, and found it to be a cost-effective means to increase biogas production. Central Gen has more than adequate capacity to use all the biogas produced by 
the facility, and as more biogas is produced, less natural gas needs to be purchased. Plant staff estimates that biogas production increases between 12 and 18 percent because of APT. The lower figure of 12 percent is gained with 16 hours per day APT at $20 \mathrm{mg} / \mathrm{L}$ ferric chloride and $0.15 \mathrm{mg} / \mathrm{L}$ polymer. The higher figure of 18 percent is obtained with increased chemical addition (ferric chloride at $30 \mathrm{mg} / \mathrm{L}$ and polymer at 0.22 $\mathrm{mg} / \mathrm{L}$ ).

APT has reduced the need for secondary treatment, resulting in energy savings. Before APT, the primary treatment process removed about 65 percent of total suspended solids; with APT the plants achieve 80 percent removal. Increasing the amount of primary solids sent to the anaerobic digesters results in increased biogas production, equivalent to 3,000 kilowatts.

Another benefit achieved through APT is reduction of the amount of biosolids that must be disposed offsite. Less biomass is produced in the secondary process. Therefore, less biosolids must be hauled offsite, resulting in reduced vehicular emissions and conservation of nonrenewable fuels.

\section{Other Modifications}

Besides advanced primary treatment, CSDOC has implemented other process changes designed to reduce energy consumption. These include the following:
- Dissolved air flotation (DAF) process reductions

- DAF fan turned off

- Transformer turned off

- $\quad$ Reduced operation of aerators

- Dewatering fan turned off

- Elimination of scrubber recirculation pumps associated with obsolete scrubbers.

- Lighting energy conservation

Use of gravity feed reduced the need for pumping, and the facility realized substantial energy savings by insulating the digester domes.

\section{Pretreatment Program Effects on Energy Conservation}

Imposing mass-based limits on BOD discharges from industrial users has contributed to the Districts' ability to reduce its energy use. In the past, the plant observed dramatic increases in influent BOD during the food processing season. One industry alone discharged up to 70,000 pounds of BOD per day over the two to three month season. CSDOC now limits discharges from food processing industries to 10,000 pounds per day average, and 15,000 pounds per day maximum BOD. Plant staff has calculated the total reduction in BOD discharged by industry to be equivalent to 12 MGD of secondary treatment on average, peaking at up to 50 MGD of secondary treatment for several weeks at a time. The staff estimates that energy use is reduced by 500 kilowatts per year by these efforts. 


\section{Benefits of the Energy Conservation Program: Air Emissions Reductions}

CSDOC cites concerns with meeting air emissions requirements as one of two factors driving their energy conservation efforts. Southem California air regulations are among the most stringent in the country. Both CSDOC and Hyperion are subject to local regulations promulgated by the South Coast Air Quality Management District (SCAQMD). SCAQMD regulates emissions of sulfur dioxides from stationary source internal combustion engines, and sets limits on the allowable content of sulfur in gaseous fuels.

SCAQMD also requires wastewater treatment plants to develop risk assessments, and bases influent volume allowances on the results of the risk assessments.

Substitution of biogas for natural gas has enhanced the CSDOC plants' ability to meet air quality requirements. Because biogas has a heat value approximately one-half that of natural gas (LHV $=\mathbf{5 5 0}$ for biogas compared to $950 \mathrm{Btu}$ for natural gas), biogas burns more slowly and more completely. Ferric chloride is added to the digesters to control sulfides and odor, and the gas is chilled to condense out water vapor.

The following table shows the maximum emission characteristics of the Cooper Bessemer engine generators installed at the CSDOC plants.

\begin{tabular}{|c|c|c|}
\hline gotion & 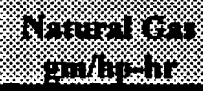 & 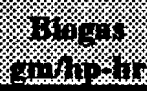 \\
\hline Orides of nitrogen & 1.0 & 0.9 \\
\hline Carbon monoxide & 3.0 & 3.0 \\
\hline Nonmethane hydrocarbons & 0.75 & 0.3 \\
\hline Particulates (gm/dry std. cublc foot & 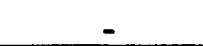 & 0.00026 \\
\hline
\end{tabular}

CSDOC specified parameters for the engine generators' performance in the contract with the supplier. Performance parameters included exhaust emissions, generator output, and engine fuel consumption. Penalties for noncompliance with these parameters were specified in the contract.

\section{Financial Benefits}

CSDOC cited high power costs as a factor that drove the decision to install Central Gen. The $\$ 65$ million cost for Central Gen and all associated projects will be recovered in about seven years because of the savings achieved by this project. 
Before construction of Central Gen, CSDOC calculated the savings resulting from its existing energy conservation program in fiscal year 1991-1992. During this year the facility reduced electrical power purchases by biogas fueling of engines, process changes, lighting energy conservation, peak load shifting, and reduction of loadings to the secondary process. CSDOC estimated the total savings from these programs at $\$ 4,101,800$. Flow decreased by 16 percent from June 1991 to June 1992 due to the drought, and this contributed about 12 percent of this savings. Over the approximately 30 years that CSDOC has been using biogas as a fuel, approximately $\$ 2$ million per year has been saved.

The following table summarizes energy conservation savings realized in fiscal year 1991-92.

\begin{tabular}{|c|c|c|}
\hline 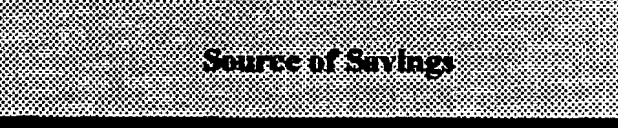 & (1) & 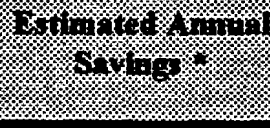 \\
\hline Use of blogas to power pumps & 2,625 & $\$ 1,464,000$ \\
\hline Advanced primary treatment & 1,700 & $1,200,000$ \\
\hline Other process changes (DAF, blower, etc) & 792 & 569,100 \\
\hline Source control BOD reduction & 500 & 350,000 \\
\hline $\begin{array}{l}\text { Water conservation (pumping costs from } \\
6 / 91 \text { to } 6 / 92 \text { ) }\end{array}$ & 500 & 315,000 \\
\hline Callfornin Energy Coalition rebates & - & 40,000 \\
\hline Lightlng conservation & 126 & 88,500 \\
\hline Peak load shinting & - & 75,200 \\
\hline TOTAL & & $\$ 4,101,800$ \\
\hline
\end{tabular}

With Central Gen on-line and able to fully use the biogas produced, the calculated savings in 1993-94 are substantial. The plant staff estimates savings totaling 12,630 kilowatts, worth about $\$ 8,850,000$. 
Residuals Use and Energy Conservation

The following table provides a breakdown of components of the savings.

\begin{tabular}{|c|c|c|}
\hline 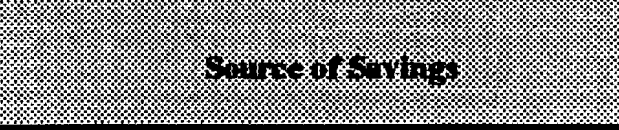 & Kry & 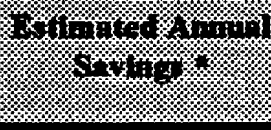 \\
\hline $\begin{array}{l}\text { Blogas power production: } \\
\text { Normal plant operation } \\
\text { Additional gas from APT operation }\end{array}$ & $\begin{array}{l}7,800 \\
1,000 \\
\end{array}$ & \\
\hline Reduced secondary treatment due to APT & 1,700 & $1,200,000$ \\
\hline Other process changes (DAF, blower, etc.) & 1,000 & \\
\hline Source control BOD reduction & 500 & 350,000 \\
\hline Water conservation & $\mathbf{5 0 0}$ & 315,000 \\
\hline Lighthg conservation & 126 & 88,500 \\
\hline TOTAL & 12,630 & $\mathbf{\$ 8 , 8 5 0 , 8 0 0}$ \\
\hline
\end{tabular}

* Savings are calculated at $\$ 0.08$ per kilowatt hour 


\section{City of Los Angeles Hyperion Wastewater Treatment Plant}

\section{Facility Description}

The Hyperion Wastewater Treatment Plant receives an average daily flow of 320 to 400 MGD (the lower flows reflecting recent water conservation efforts). Upstream wastewater reclamation plants discharge biosolids to Hyperion, resulting in an influent wastestream containing 360 to $400 \mathrm{ppm}$ of total suspended solids. About 190 MGD receives secondary treatment by activated sludge. The facility currently discharges partial secondary-treated wastewater under a consent decree: however, construction is underway to provide full secondary treatment.

The Hyperion Energy Recover System (HERS) came on-line in 1987. HERS generates energy from biosolids using two distinct methods:

1. Biogas from anaerobic digestion fuels three gas turbines. Each turbine has the capacity to produce 4,500 kilowatts of electricity. Waste heat from the turbines is fed to heat recovery boilers to make high pressure steam. Generators driven by two turbines use the steam to produce more electricity.
2. Biosolids from the digesters are dehydrated and the powder is burned in a fluid bed gasification multi-stage combustion chamber. About 20 percent of the total biosolids produced are burned in this process. Ash from this combustion process is currently used in an offsite cement manufacturing process. Hyperion's total average electrical production is $\mathbf{2 0}$ megawatts.

The City estimates that HERS saves $\$ 12$ million in electricity costs per year.

\section{Energy Recovery from Biogas}

Biogas provides approximately 80 percent of the energy produced onsite.

Hyperion's anaerobic digesters produce an average 7.5 million cubic feet per day of biogas. Under normal operating conditions, all of the biogas is captured and used to either generate electricity (via gas or steam generators) or to make steam for heating purposes in the plant. Hyperion's biogas has a fuel value of 600 $650 \mathrm{Btu} /$ cubic foot. Figure 3 is a schematic of the distribution of the daily gas production. The schematic also shows where natural gas is introduced to augment the fuel supply. 
Iron compounds are added upstream of the primary settling basins and to the digesters to control hydrogen sulfide, at an annual cost of $\$ 1.5$ million. Even so, biogas contains 60 to $100 \mathrm{ppm}$ of hydrogen sulfide. The high sulfide content may result from sulfur bacteria in the collection system acting on the biosolids produced by upstream water reclamation plants. Increasing the amount of iron added to the process tanks is not economically feasible, so biogas is usually treated in a Stretford desulfurization unit to produce a product with a content of less than $40 \mathrm{ppm}$ of hydrogen sulfide. To pass it through the Stretford unit, the gas is subjected to "intermediate" pressure (40 psi) as it comes off the digesters. The Stretford unit produces about 50 to 60 pounds of sulfur daily. The annual cost of operating the unit is $\$ 20,000$.

After desulfurization, the boilers can directly use the biogas as fuel to produce steam for digester heating and biosolids drying. However, most of the gas is further pressurized, mixed with natural gas, and used to power three gas turbines, each with a capacity of 4,500 kilowatts of electricity.

Waste heat from the turbines is fed to heat recovery boilers to make high pressure steam. Generators driven by steam turbines use the steam to produce more electricity. By using this "combined cycle" approach to produce power from both gas and steam turbines, the plant increases its net electrical production by 50 percent over that of a conventional "simple cycle" power plant (a plant that uses only one kind of generator). The fluid bed gasification combustion chambers which had originally been designed only to bum solids have been modified so that they can use biogas as fuel. Therefore, even when the CarverGreenfield process is down, the gasifiers can be used to produce steam to power the steam turbine generators. 
Residuals Use and Energy Conservation

Figure 3: Schematic of the distribution of daily gas production

\section{HYPERION TREATMENT PLANT \\ Avg. Daily Gas Distribution}

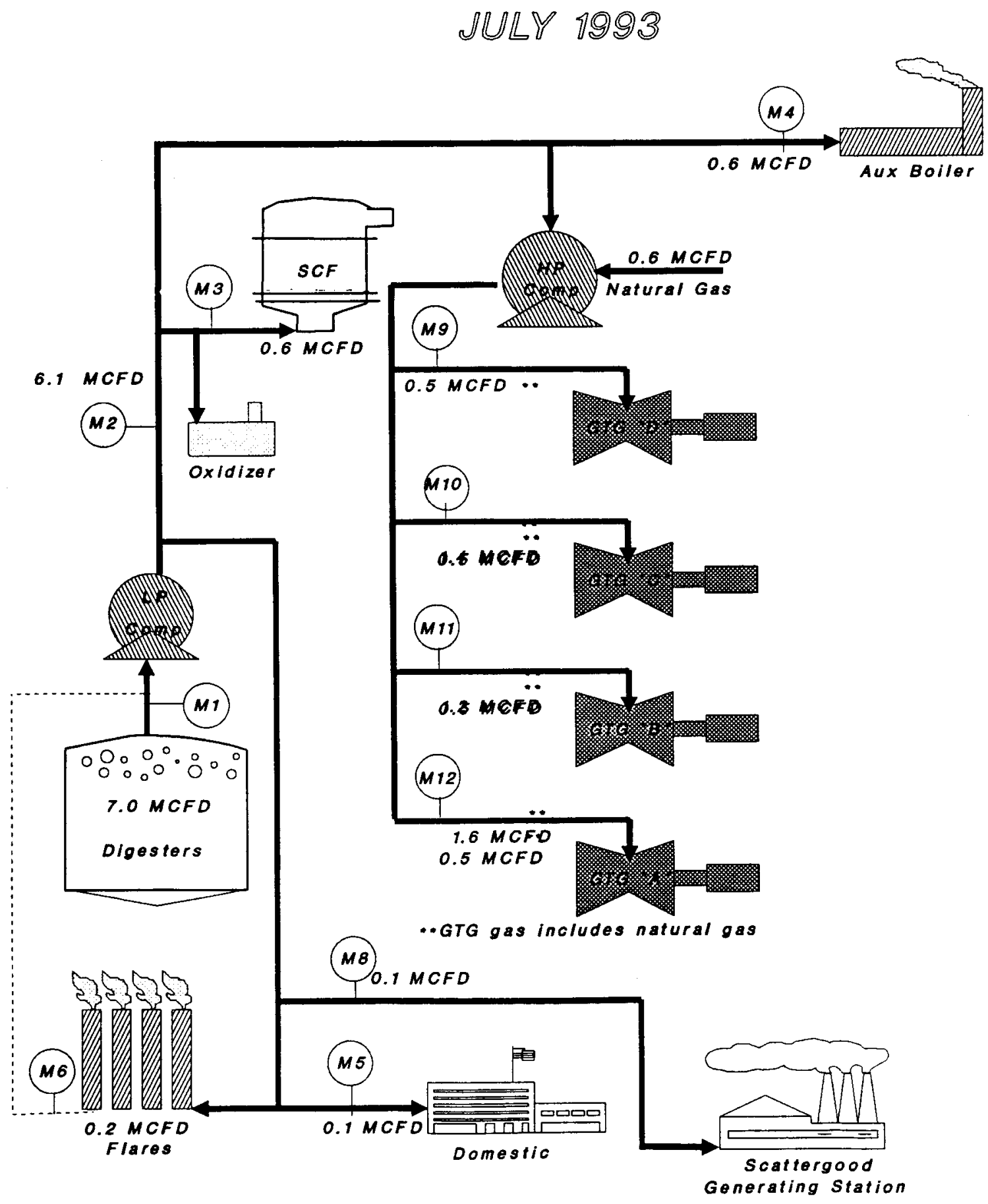


The following table shows the amounts of biogas used for each activity:

\begin{tabular}{|c|c|}
\hline 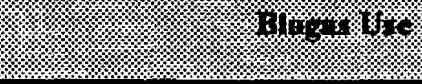 & 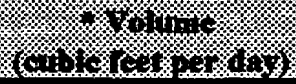 \\
\hline Flares & 200,000 \\
\hline Plont steam & 800,000 \\
\hline Fluid bed gas afterbumers & 600,000 \\
\hline Fume incherator & $0-100,000$ \\
\hline Digester heating & 800,000 to 1 million \\
\hline Gas turblne generators & 4.1 million \\
\hline Total biogas production & 7 million \\
\hline
\end{tabular}

* Values are approximate and reflect production during July 1993.

The facility currently uses about 600,000 cubic feet per day of natural gas to supplement biogas production. This figure represents about 8 percent of the total amount of gas burned at Hyperion.

\section{Energy Recovery from Biosolids}

Biosolids from the digesters are dehydrated in one of three trains of a Carver-Greenfield process, and/or in one of two steam dryers. The resulting powder is burned in a three-train fluid bed gasification/multi-stage combustion chamber to produce steam. This process provides, on average, about 20 percent of the total energy generated onsite. The HERS solids handling schematic is presented in Figure 4. The facility has recently added two new rotary disc steam dryers to increase biosolids drying capacity, and thus, energy recovery capacity.
Digested biosolids are removed from the digesters and screened; polymer is added and the screened biosolids are directed into centrifuges. Solids cake comes out of the centrifuges with a solids content of 23 to 24 percent. A carrier oil transports cake to the steam-heated drying pathway where water is evaporated. The CarverGreenfield drying system currently processes 230 to 240 tons of wet biosolids per day.

Approximately one pound of dry powder is obtained for each 4.3 pounds of steam fed to the dryers. The powder has an energy content of 5,500 to 6,000 Btus per ton, depending on the amount of oil in it. On average, the dryers produce about 45 tons per day of powder. During July 1993, the facility produced 840 tons of dry powder and 18,170 gallons of sludge oil. However, an average two of the 
three powder combustion trains were down throughout the month; therefore, the facility only burned 545 tons of powder during July 1993.

Dried biosolids are fed into the fluid bed gasifiers along with a controlled amount of air. No additional fuel is necessary to sustain the pyrolization that occurs here. Additional burn occurs with controlled air addition in the two afterburners. Flue gas from the system is passed through heat recovery boilers to produce steam, which in turn drives generators to produce up to 10 megawatts of electricity at design loads. The net power generated is 200 kilowatts per ton of powder.

Powder from the Carver-Greenfield process must be transported and stored under nitrogen to prevent autogenic combustion. The dryers use several chemicals, including antifoam, antiscale and dispersant. The total cost of chemicals for the drying process (including nitrogen and the oil for cake transport) is about $\$ 35,000$ per month.

About 75 percent of the cake ( 800 wet tons per day) is hauled offsite for land application, but ultimately the plant expects offsite disposal to decrease to approximately 50 percent. An additional 200 wet tons of solids daily will be generated beginning in January 1998 as Hyperion achieves full secondary treatment. The plant staff expects gas production to increase by 50 percent over current levels, to about 12 million cubic feet per day. By installing two new steam dryers, the facility will obtain an additional daily capacity of 350 wet tons of biosolids. Two new boilers and two 16 megawatt steam turbines will also be added, bringing the total rated capacity of the power generation facilities to about 55 megawatts.

\section{Process Modifications}

In advanced primary treatment, ferric chloride and polymer are added to the primary tanks to improve solids settling. As a result, primary treatment removal efficiencies are routinely 85 percent for total suspended solids and 50 to 55 percent for BOD.

Hyperion has carried out several modifications designed to increase the efficiency of energy use at the plant, including both demand side and generation side changes. These include:

- $\quad$ Reduction of the number of blowers in aeration tanks

- Optimizing loadings to centrifuges, which have various design loadings

- Minimization of the use of flares

- $\quad$ Retrofitting the fluidized bed gasifiers for use of biogas

- $\quad$ Optimizing the effluent pumping plant. 
Residuals Use and Energy Conservation

Figure 4: HERS solids handling schematic

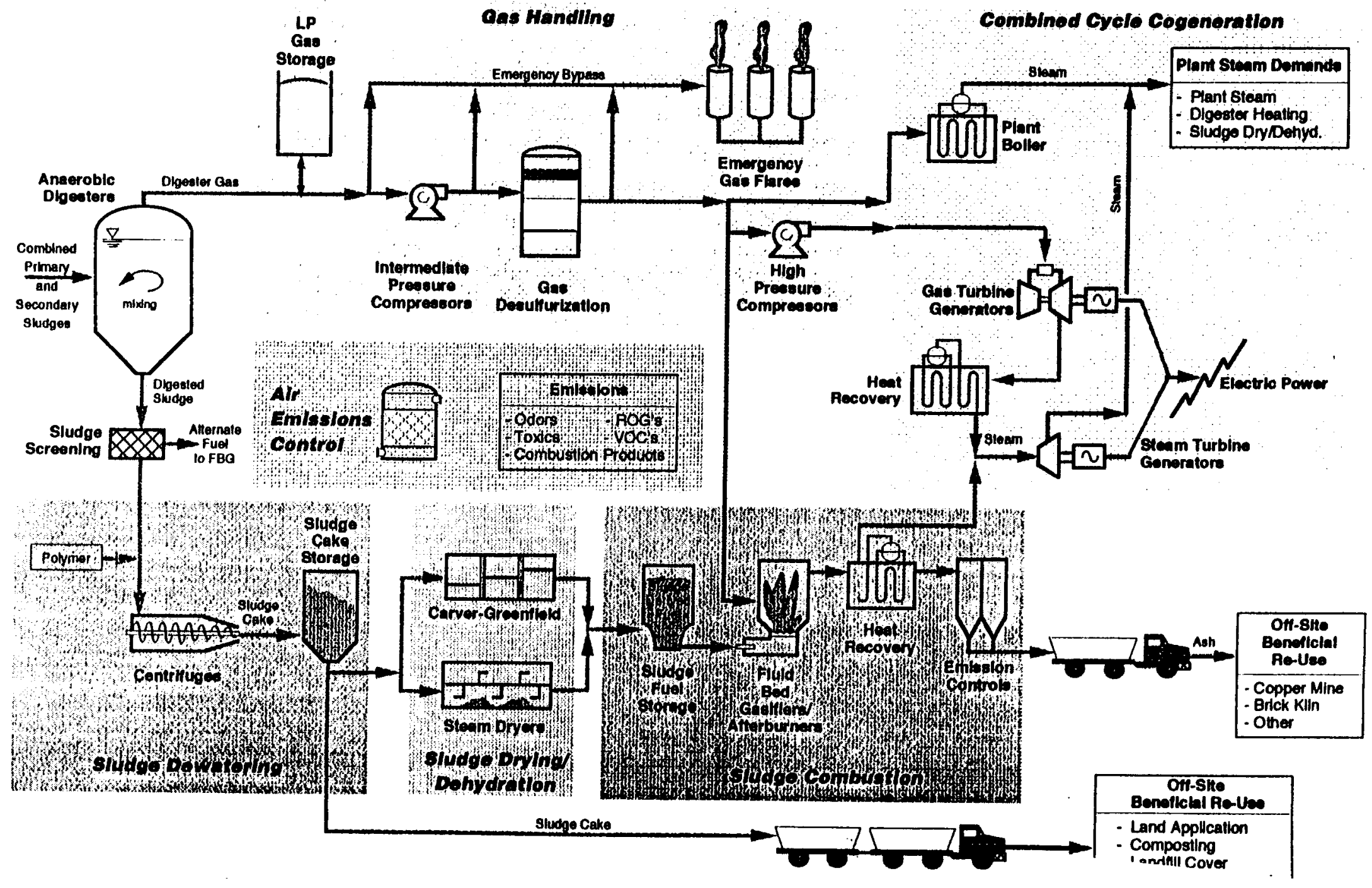


Hyperion currently operates three digesters as two-stage digesters in a series, and has plans to operate all the digesters in this manner. This mode of operation allows reduction of the retention time while increasing the destruction of pathogens and production of biogas. The facility has plans to install egg-shaped digesters as future capacity becomes necessary, as they expect the egg shape will allow for better mixing and require less cleaning.

Modifications are planned to increase the efficiency of the drying process. The facility intends to install rotary-disc steam dryers to supplement the existing steam dryer system. Rotary disc dryers use steam-fed discs which rotate within a large vessel containing dewatered biosolids cake. The discs conduct heat to the cake, raising its temperature to the boiling point of water and evaporating most of the moisture.

Modifications to the existing combustion facilities are planned to enable other plant residuals to be treated. Grit and screenings may be fed through the process to eliminate odors and reduce the amount of material that must be disposed of at landfills. Screenings, which include a high organic content, are expected to add to energy generation capacity.

\section{Benefits of the Energy Conservation Program: Air Emissions Reductions}

Hyperion is able to meet stringent local regulations promulgated by the South Coast Air Quality Management District (SCAQMG). SCAQMD regulates air emissions through health risk assessments. Hyperion's staff has the technical expertise to perform these risk assessments onsite. Staff can experiment with ways of reducing the identified risks.

Compared to a traditional power plant, biosolids burning is a cleaner process, emitting only about 50 percent of the nitrous oxides that would be expected from a comparably sized natural gas-fired plant. Hyperion staff has found that burning biogas in the gas turbines results in lower nitrous oxides emissions than buming natural gas, because the higher level of carbon monoxide in the biogas serves as a sink. Secondary oxidation of carbon monoxide yields carbon dioxide. Thermal oxidizers fueled by biogas control fumes from the drying processes.

\section{Financial Benefits}

In July 1993, the power plant produced $11,312,000$ kilowatt hours of electricity, equivalent to about $\$ 837,000$. Hyperion's steam generators and gas generators have a total combined electrical generation capacity of 25.2 megawatts; however, 17 to 20 megawatts is the normal operating rate. About 1 megawatt is exported for sale; the plant uses the remainder onsite. HERS reportedly saves Hyperion about $\$ 12$ million per year in electricity costs. 
The following table summarizes the operating costs at Hyperion's biosolids drying facility during July 1993:

\begin{tabular}{|l|l|}
\hline Labor -59 employees & \\
\hline Chemicals & $\$ 210,614$ \\
\hline Utilities & 47,036 \\
\hline Maintenance & 80,620 \\
\hline Total Gross Operating Cost & 46,389 \\
\hline \multicolumn{1}{|c|}{ Energy Production } & $\$ 384,659$ \\
\hline Total Net Operating Cost & $-64,617$ \\
\hline
\end{tabular}

These costs are based on an estimated value of \$62 per ton of powder and \$0.69 per gallon of sludge oil.

Over the period 1992 through 1993, monthly electricity purchases ranged from less than zero (when the facility receives a credit for producing more electricity than can be used onsite) to about $\$ 460,000$. As an example, in July 1993 Hyperion consumed an average 389 megawatt hours daily, and generated an average 365 , for a total daily shortfall of 24 megawatt hours. The total cost for energy during July 1993 was $\$ 865,000$. To supplement its onsite production and make up for the shortfall, the facility bought electricity at a total value of $\$ 202,000$. Thus, Hyperion generated over 75 percent of the needed energy onsite during this month. 
The following table provides a breakdown of electrical usage at the plant in July 1993.

\begin{tabular}{|c|c|c|}
\hline$\sqrt{*}$ & $\%$ & $4 \%$ \\
\hline Secondary Treatment & $\mathbf{S 2 9 8 , 0 0 0}$ & 34.3 \\
\hline Bulldinga/Facillities & $\$ 129,000$ & 15.0 \\
\hline Blosolids Dewatering & $\$ 123,000$ & 14.2 \\
\hline Primary Treatment & $\mathbf{S 8 0 , 0 0 0}$ & 9.2 \\
\hline Cogeneration & $-577,000$ & 8.9 \\
\hline Biosolids Combustion & $\$ 62,000$ & 7.2 \\
\hline Digesters & $\$ 61,000$ & 7.1 \\
\hline Dehydration & $\$ 35,000$ & 4.0 \\
\hline Total & $\$ 865,000$ & 100 \\
\hline
\end{tabular}

The value of the electrical production from burning biosolids does not presently cover the costs of processing the biosolids onsite. As an example, during July 1993 the Hyperion power plant produced electricity equivalent to $\$ 837,000$. On average, 20 percent of the facility's electricity generation comes from burning biosolids. Thus, burning biosolids produced electricity worth $\$ 167,000$ in July 1993. During this month Hyperion processed 4,493 tons of solids cake through the drying facility, at a (gross) cost of $\$ 384,700$. The net cost of handling the biosolids onsite was $\$ 217,700$ for the month. At $\$ 35$ per ton, it would have cost only $\$ 157,300$ to send the 4,493 tons of solids cake offsite, saving about $\$ 61,000$ over costs to process the biosolids onsite.

However, the economics of biosolids handling at Hyperion will change with the planned additions of dryers and other energy recovery equipment that can handle more biosolids. These changes are expected to make the process competitive with offsite management. The HERS staff estimates that with two drying trains operating, 5 to $7 \mathrm{MW}$ of electricity (worth about $\$ 3$ million) could be exported. Costs to process biosolids onsite should fall as low as $\$ 109$ per dry ton, compared to $\$ 132$ for offsite management. 
Power generation varies based on needs for equipment maintenance and repair. In three of the 12 months in fiscal year 19921993, HERS generated more power than Hyperion consumed. Figure 5 contrasts the power generation by HERS with Hyperion's power consumption in the period from August 1992 through July 1993.
The gas turbines require a major overhaul every 10,000 to 12,000 hours (1 to 1.5 years). This schedule is more frequent than what would be required for a larger sized turbine. Thus, in this respect, HERS does not achieve the economy of scale that would be seen at a conventional power plant.

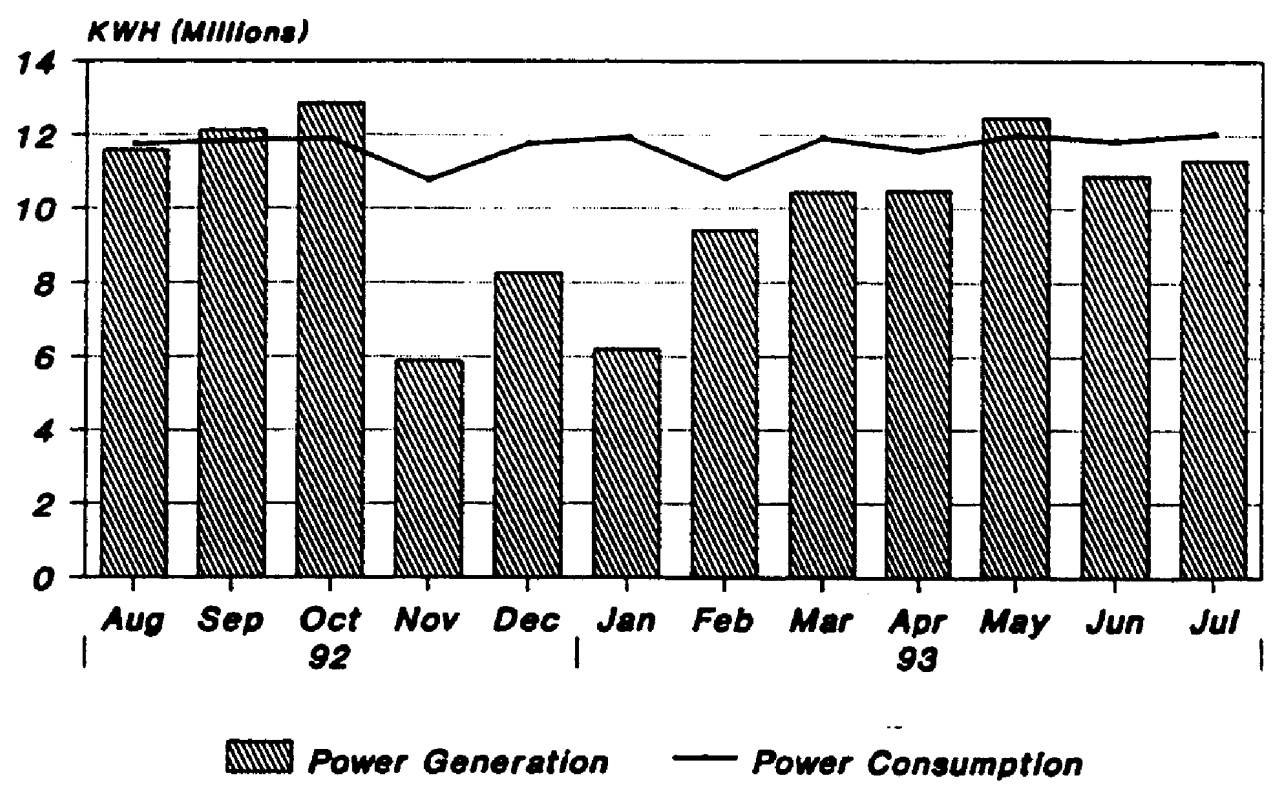

Figure 5: Power generation versus consumption at Hyperion 


\section{Sunnyvale Water Pollution Control Plant}

The Sunnyvale Water Pollution Control Plant (WPCP), in California incorporated use of biogas in its original plant construction in 1956, and has been successfully carrying out energy conservation ever since. Recently, the City has implemented or planned some unique new methods to increase energy recovery and further the pollution prevention and water conservation goals of the plant. These innovative energy recovery options include transfer of suspended solids biomass harvested from the oxidation pond effluent to the digesters to increase gas production, and plans to extend the energy recovery operation to the use of gas from the adjacent municipal landfill. Sunnyvale expects to be able to meet 100 percent of the plant's energy demands through use of a combination of landfill gas and biogas.

\section{Facility Description}

The original 7.5 MGD primary plant was designed to service a population of 10,000 and to provide separate treatment for a seasonal cannery load of 4.0 MGD. The plant was equipped with two 55 -ftdiameter anaerobic digesters and two biosolids drying lagoons. Biogas produced by the anaerobic digestion process was collected and piped to operate three engines, each of which drove a 100 -hp raw wastewater pump and a 50-hp pre-aeration blower. Enginedriven pumps were used because they could cope with the great range between minimum and maximum flow rates ( 1 to 50 MGD) and could provide the flexibility required to operate separate domestic and seasonal wastewater treatment systems. This flexibility eliminated the need for intermittent pumping and large wet wells. For the first few years of operation, the pump engines operated on biogas 20 to 40 percent of the time. The facility used waste heat from the engines to produce steam for digester heating and for space heating of the plant's main building.

In the early 1960 's Sunnyvale's population increased by 500 percent to 60,000 people. Plant expansions in 1965 and 1968 increased the treatment plant's capacity to 15 MGD, incorporating primary and secondary wastewater treatment. These expansions included a third 55-ft-diameter anaerobic digester and a 440-acre oxidation pond with a four-pump circulation pumping station and a remote three-engine-generator facility to provide power for the pumps. The three engine-generators use either natural or biogas for fuel.

Also in 1968, the plant's solids handling facilities were improved with the addition of a third biosolids lagoon and a hot water reservoir system to replace the original direct steam injection and heating system. After this improvement, the biogas supply provided an estimated 50 percent of the engine fuel and plant-heatin requirements. The City increased the plant capacity and constructed a fourth $70-\mathrm{ft}$. diameter anaerobic digester in 1972. 
In 1978, due to substantial upgrading of effluent discharge regulations--including the ammonia removal requirements-upgrades were made to add fixed growth reactors (FGRs), air flotation units (AFTs), dual media filters, and breakpoint chlorination and dechlorination equipment. As part of this construction, the facility modified the electrical distribution system to allow the circulation pump engine-generators for the oxidation ponds to be used to supplement general electrical power needs. Currently, aeration of the oxidation ponds is done only on an asneeded basis.

Sunnyvale increased treatment capacity to 22.5 MGD when the population exceeded 100,000 , with a final upgrade to 30.0 MGD in the early 1980 's. Seasonal treatment capacity for cannery discharges was no longer needed when canneries were relocated out of the service area in 1983. Due to water conservation activities by domestic, commercial and industrial users, the annual average influent to the plant in 1992-1993 was 13.4 MGD.

\section{Description of the Technologies}

The energy recovery system at the WPCP combines the use of biogas as an engine generator fuel and boiler fuel, and uses heat recovery from engine-cooling and exhaust stack systems to supplement plant energy requirements. The components of the energy recovery system are discussed below.

\section{Biogas Production and Use}

A design goal for the original Sunnyvale wastewater treatment plant was to make maximum use of biogas. This objective has remained an important consideration in each of the subsequent plant modifications. The 1956 plant included two digesters; in the 1960's three gasfueled engine-generators were added to the plant to power recirculating pumps for the oxidation ponds. The remote powergenerating facility was provided because the recirculation pumps are approximately one mile from the digesters. A full parallel electrical distribution board is present so that any or all of the plant electrical circuits can selectively use power generated either within the plant or commercially.

Digesters are operated at $100^{\circ}$ Fahrenheit as completely mixed primary units. Each digester is equipped with four gas tubes that run from the floating dome top to the bottom of the digester. The tubes facilitate agitation and mixing. Baffle plate condensers are used to remove moisture from the biogas. Sunnyvale has some gas storage capability at the tops of the digesters, and at present has no plans to add external gas storage.

Currently, a blend of biogas and natural gas powers three 110 kilowatt "enginators," or engine generators, which together produce 330 kilowatts of power. Natural gas is purchased from the local supplier and blended with air to lower the heating value to about $550 \mathrm{Btu}$, so that it is equivalent to that of biogas. The biogas piping system joins with the 
natural gas piping system, and the two gases are blended to maintain a constant flow to the pump and generator engines and to maintain adequate pressure in the gas header. The biogas piping system associated with each of the four digesters is equipped with a flow meter, flame trap and pressure relief valve. Headers are set to maintain eight inches of water column pressure. If the water column exceeds eight inches, the excess gas is flared through pressure relief valves which are automatic and set to maintain the optimal header pressure. The flares can be operated manually if the automatic system fails.

Recent plant data show that biogas production for the 12 months between December 1991 and November 1992 averaged 172,000 cubic feet per day. The monthly average biogas production varied from a low of 126,000 cubic feet per day in July, to a high of 235,000 cubic feet per day in November. The blend of biogas and natural gas meets roughly 30 percent of the plant's 1,000 kilowatt energy demand.

In 1964, total gas consumption was approximately 60 million Btu per day in 1964, of which only 1 million Btu was supplied by natural gas. In 1976, total consumption averaged 107 million Btu per day, of which approximately 22 million Btu was supplied by natural gas. Over this period, the use of biogas reduced Sunnyvale's daily natural gas consumption on average by 60 million Btu. This is equivalent to the daily natural gas use of 150 typical American households. Figures from 1991-1992 show that biogas production at Sunnyvale has continued to increase, averaging about 95 million Btu per day. This increase occurred despite the loss of the canning wastestream, which contributed to increases in gas production before the early $1980^{\prime}$ s.

Increases in biogas production since the early 1980 's are largely attributable to two activities. First, Sunnyvale conducted studies that concluded that suspended solids removed from the oxidation pond effluent by the AFTs could be fed to the digesters. Approximately 30 percent of the solids removed by the AFTs are directed to the digesters. The plant recycles the remaining 70 percent of the solids to the ponds. Sunnyvale calculates that the energy which could be obtained from digestion of these solids is close to that obtained from primary biosolids. The City estimates that gas production will increase a further 25 percent when all of these solids are sent to the digesters, to approximately 224,000 cubic feet per day. Expressed in thermal units, estimated future biogas production is 5.1 million Btu per hour.

In the second effort at increasing gas production, Sunnyvale abandoned the use of alum for coagulation in the AFTs, and substituted polymer. Elimination of alum reduced the toxicity of metal inhibition and has allowed for increased gas production. The dependability of gas production and the available digester capacity has increased. In addition, the polymer is an organic compound which contributes to the energy recovered from digestion. 


\section{Waste Heat Recovery}

An important design feature of the Sunnyvale plant is the use of waste heat from the gas-fueled engines to provide both process heat for the digestion and chlorination systems, and space heating for various buildings at the treatment plant. Currently, waste heat is recovered in three systems: (1) pump-engine heat recovery, (2) generator-engine heat recovery and (3) stack heat recovery. These systems may be supplemented as required by the low-pressure, gas-fired steam boiler; however, typically more heat is obtained from the heat recovery systems than is actually needed in the plant. Heat from all sources is converted into hot water for use throughout the plant. Presently, the plant does not use excess heat for cooling needs.

All engines operate on high-temperature ebullient cooling $\left(212^{\circ}\right.$ to $\left.220^{\circ} \mathrm{F}\right)$. Cooling water circulates through the engines by convection and the lifting action of steam bubbles. The main pumpengine heat recovery system reclaims the waste heat from both the engine's cooling system and the engine's exhaust-silencing system. The system operates at a slight positive pressure ( 5 to $7 \mathrm{lb} / \mathrm{in}^{2}$ ), and the temperature of the circulating cooling water leaving the engine is always above $212^{\circ} \mathrm{F}$. Heat is recovered from the system by transferring it from lowpressure steam to hot water in a condenser heat exchanger. Excess heat is discharged as steam to the atmosphere through a pressure relief valve.

The generator-engine heat recovery system operates at atmospheric pressure; therefore, the temperature of the cooling water leaving the engine is $212^{\circ} \mathrm{F}$.

Operation at atmospheric pressure is much simpler than operation at higher pressures since the open steam discharge pipe from the condenser acts to provide both pressure and vacuum relief. Atmospheric pressure operation eliminates the ability to recover the waste heat from the generator-engines' exhaust silencers. However, this heat is not needed for use in the plant. When the heat exchanger of the generator-engine condenser cannot cope with all the heat recovered, the excess is discharged to the atmosphere as steam.

Isolation of the engine-cooling system from the hot-water-heating system assures the integrity of each system. Hot water is piped throughout the plant as part of a recirculating heat reservoir system. Secondary heat loops, which operate in parallel with the main circulation system, are equipped with their own blending valve and circulating pump and are provided to satisfy process and space heating requirements. The main heat reservoir and the secondary loops for chlorine evaporation and space heating operate between $180^{\circ} \mathrm{F}$ and $210^{\circ}$ $\mathrm{F}$, while the secondary heat loops for biosolids heating are maintained between $140^{\circ} \mathrm{F}$ and $160^{\circ} \mathrm{F}$.

\section{Operation and Maintenance}

The original plant influent pumps were designed to pump a minimum flow in dry weather of 1.0 MGD and a peak flow in storms of 50 MGD. During the past 20 
years, the City has reduced infiltration into the sewer systems such that minimum flows are now 6 MGD while peak flows are only 32 MGD. Three dual-fuel engines each drive a 100-hp raw wastewater pump and a 50-hp preaeration blower. During installation in 1956, the pump engines used dual suction-type carburetors. The weight of the digester covers maintained two inches or more of water column pressure in the digester system. Engine fuel was changed from biogas to natural gas when the pressure in the biogas system fell below two inches and reverted to biogas when the biogas pressure built up to four inches. Waste gas burners came on when biogas pressure built up to 8.5 inches of water column pressure.

In 1969, the City installed three 330 kilowatt-capacity engine generators to provide power for the four 60 -hp pond recirculation pumps. The carburetors on the engine generators were designed to use the same fuel system as the main pump engines. However, booster gas compressors were installed to supplement natural system pressure. These compressors supplied gas to each engine carburetor at a much higher working pressure. Problems occurred almost at once with this fuel system. Despite good maintenance, the gas compressors tended to draw air around the shaft packing, causing operational problems with the carburetors and with the control of the digesters. The plant abandoned use of the booster gas compressors due to these operational problems and phasing out of the original carburetors by the manufacturer. The facility increased gas piping sizes and installed new single, positive pressure carburetors on all six engines.

The new carburetors operate as follows: the fuel supply is switched from biogas to natural gas when the pressure in the biogas system falls to two inches of water column pressure. The fuel supply returns to biogas when the pressure in the biogas system increases to six inches of water column pressure. This system maintains at least two inches of water column pressure within the biogas system. As long as this minimum pressure is maintained, there is no danger of air being drawn into the digester system.

Sunnyvale has not made any efforts to upgrade to energy efficient engines because of other facilities' experiences that such engines are not successful in the long run. However, other energy efficient equipment installed at the plant has proven successful. Special chlorine injectors are used to supply chlorine into the flow system, providing a cost savings of approximately $\$ 20,000$ per year. The propellers associated with the main sewer pump system have been coated with a coating that reduces drag and increases water flow and pump efficiency.

Sunnyvale uses a preventive maintenance schedule which is designed to identify potential problems before they occur. A positive feature of the system has been the low maintenance requirement over the years of operation. The three engine generators essentially run full-time. The main engines running time is more variable, but works out to about one and 
one-half engine on full-time.

The main engines installed in the 1950's and the engine generators installed in the 1960 's are still in use today. These engines have been through a complete overhaul and several rebuilds, and are in good operating condition. Engine failure has never been a problem or prevented the plant from providing treatment. The main pump engines are scheduled for overhaul every six years, based on the number of running hours. Plant staff recondition the engine generators every four years.

\section{Other Conservation and Pollution Prevention Activities}

Sunnyvale is currently working on several other energy conservation activities including: constructing a 1.6 megawatt power generation facility that will use methane gas from the adjacent landfill, combined with anaerobic biogas from the WPCP to fuel engines and generators that supply electricity to the WPCP, a $\$ 14$ million water reclamation project, and construction of a tile dewatering facility.

\section{Landfill Gas Production}

The Sunnyvale WPCP is located next to the municipal landfill. The landfill has received its final load of solid waste, and was closed on October 1, 1993. Landfill gas (LFG) is produced by bacterial decomposition of the organic portion of refuse in the absence of oxygen. Once begun, the rate of decomposition reaches a peak within a few years, then gradually declines as the decomposable organic material is depleted. In inactive landfills such as Sunnyvale, the production of LFG is dependent on the portion of previously disposed refuse which has yet to be converted to LFG.

LFG is a mixture of methane and carbon dioxide, with trace contaminants. The concentration of methane in undiluted LFG has been measured between 55 percent and 65 percent at the Sunnyvale landfill. Trace contaminants in LFG can affect engines primarily due to the presence of chlorine (carried in compounds such as trichloroethylene), which produces hydrochloric acid during fuel combustion. An advantage to LFG as a generator fuel is its much lower hydrogen sulfide concentration compared with that of biogas. The concentration of hydrogen sulfide in Sunnyvale's biogas averages 1,270 parts per million, but when blended with LFG will result in a reduced concentration that should lower emissions and improve equipment longevity.

To meet Bay Area Air Quality Management District (BAAQMD) regulations, at present all LFG is flared to the atmosphere. The proposed energy conservation project will collect LFG and use it together with biogas from the WPCP anaerobic digesters to fuel engines and generators that supply the WPCP with electricity. All of the energy needs of the WPCP will be met through a combination of these sources. The City expects that LFG will also meet some energy demands of the new solid waste transfer station next to the WPCP. The collection potential for LFG in 1995 is 
estimated to be 1.2 million cubic feet per day. The City estimates that present biogas energy production at the WPCP represents only one tenth of the energy available from $\mathrm{LFG}$.

LFG collection and use will have to be conducted in compliance with BAAQMD Rule 8-34. LFG not used as fuel must be burned or otherwise treated in compliance with the LFG system BAAQMD

Operating Permit in effect at the time.

The City expects that LFG generated by the landfill will decline during the 20-year life of the proposed power generation facility, due to gradual and continuing depletion of organic material in the landfill. Despite this decline, the City estimates that 100 percent of the energy demand of the Sunnyvale wastewater treatment plant, all of the power for the water reclamation facility (discussed below), and some power for the municipal waste transfer station will be met through use of LFG and biogas. The City projects savings in reduced purchases of electricity to be $\$ 826,400$ in FY $94-95$.

As part of this project, the plant will be fitted with two new 800-kilowatt low emission lean burn engine generators, at an estimated cost of $\$ 1.5$ million. The total cost of the LFG project is estimated at $\$ 4.47$ million. The project has received a grant from the California Energy Commission for $\$ 500,000$. At the $\$ 826,400$ annual savings in electrical costs, project payback is anticipated in approximately six years. 
Biosolids Dewatering and Drying Bed System

Sunnyvale WPCP is converting its original biosolids drying beds to a screentype biosolids drying system. The new drying system will be made up of twoinch thick tiles, with fine slits to allow water to pass through to the drainage system. Polymer will be added to biosolids as it comes off the digesters; mixing will occur in the transfer line to the biosolids beds. The tiles will be laid across the bottom of the biosolids drying bed and will induce separation as solids are captured on the surface and liquid drains through the slits in the tiles. This system is expected to reduce biosolids volume to 18 percent (by weight) of its original total volume.
The City selected tile screening for dewatering its biosolids based on cost and applicability to the biosolids' characteristics and final reuse. The cost of installing the tile dewatering system is about half what a belt press of comparable capacity would cost. Operation and maintenance costs for the tile dewatering system are low; two pumps and a grinder are the only energy expenditures associated with this dewatering system. The dewatered biosolids will be used as final cover for nearby municipal landfills. 


\section{Sanford Big Buffalo Creek WWTP, North Carolina}

\section{Facility Description}

The Big Buffalo Creek (BBC) WWTP provides wastewater treatment for a population of approximately 17,000 people. The plant has an average influent flow of about 3.52 MGD, and a design peak flow of 6.8 MGD. During major rainfall events inflow and infiltration (I \& I) may cause the flow to peak at 12 MGD. The facility was constructed in 1973 and then upgraded from 1989 to 1992. BBC is a tertiary facility with mechanical bar screening and grit removal, extended aeration, secondary clarification, mixed media filtration, and aerobic sludge digestion. Effluent is chlorinated before discharge to the Deep River.

\section{History of the Energy Conservation Program}

During the late 1970 's several U.S. oil companies violated price controls. Due to the subsequent litigation by the U.S. Government against the oil companies, certain companies were assessed and paid large settlements. The monies were dispersed, through a U.S. Department of Energy grant to the individual states. During the years of 1983 to 1986 , the North Carolina Department of Economic and Community Development, Energy Division, used part of the grant to conduct on-site energy audits of 15 wastewater treatment plants and three water treatment plants.

BBC has carried out several energy conservation actions since 1985 , many as a direct result of the energy audit. The audit found that the plant components which consumed the major power were extended aeration $(70 \%)$, influent pumping (17\%), aerobic digestion (5\%), sludge pumping $(3 \%)$, and small miscellaneous uses (5\%). 
Residuals Use and Energy Conservation

The energy audit made the following recommendations:

- Alternative A-1: A sluice gate should be installed to limit the excess storm water received at the WWTP during rainfall events. The excess flow should be bypassed to the receiving stream rather than being treated. This action would reduce wastewater pumping, return activated sludge pumping, chlorine usage, and aerobic digester supernatant pumping. The estimated installation cost was $\$ 7,000$ and the estimated annual savings $\$ 1,200$. The calculated payback was six years.

Result: A sluice gate was installed, however, the excess volume was backed up in the collection system rather than bypassed. The influent was then treated as a steady flow. In a recent upgrade the sluice gate was replaced with a "Beck" valve which automatically adjusts to return part of the influent flow to the influent wet well to maintain a constant head level and therefore constant pump operation. Continual pumping at a stable head conserves energy by eliminating electrical surges.

- Alternative A-2: A low head hydro-power producing system (turbine) should be installed on the discharge. This would result in the generation of 6 kilowatts of electrical power at a flow of 2 MGD. The estimated installation cost was $\$ 61,000$ and the estimated annual savings $\$ 4,400$. The calculated payback was 13.8 years.

Result: The WWTP did not act on this recommendation.

- Alternative A-3: A microprocessor-based energy management system should be installed which would control selected equipment to reduce power demand levels. The estimated installation cost was $\$ 15,500$ and the estimated annual savings $\$ 12,000$. The calculated payback was 1.3 years.

Result: A process control system was installed which reduced the power demand of the extended aeration process. This action is addressed in greater detail under Alternative C-1 below.

- Alternative A-4: The laboratory building should have storm windows installed, walls insulated, and an HVAC control installed. The payback was over 10 years and the energy audit calculated that the expense could not be justified.

Result: The WWTP enacted some of these recommendations during the plant upgrade.

- Alternative B-1: This alternative had four options. The first three options are based on the field tests which showed influent pump No. 2 to be the least efficient. Option one recommended the replacement of the influent pump station No. 2 pump impeller 
with a smaller impeller. Option one had an estimated installation cost of $\$ 1,600$ and an estimated annual savings of $\$ 340$. The calculated payback was 4.6 years. Option two recommended that pump No. 2 be used only during times of excessive storm water events. This option had no payback. Option three recommended the replacement of pump No. 2 with a variable speed energy efficient pump.

Result: The first option was selected by the WWTP and the impeller size was reduced. The result was that more than one pump operated at a time. The impeller size reduction proved to be beneficial during dry weather, however, during wet weather the pump cycled at a rapid rate which resulted in increased energy costs. During the plant upgrade the pumps were replaced with high efficiency winding pump motors.

- Alternative B-2: Archimedes screw pumps are used for the return activated sludge (RAS). The audit recommended that the aeration basin mixed liquor suspended solids level be reduced from $6,000 \mathrm{mg} / \mathrm{L}$ to $4,000 \mathrm{mg} / \mathrm{L}$ to reduce the volume of RAS to be pumped. The estimated annual savings was $\$ 2,500$.

Result: The screw pumps were replaced with centrifugal pumps during the upgrade.

- $\quad$ Alternative B-3: The energy audit studied the feasibility of replacing the pump impellers at the waste activated sludge (WAS) pumping station. The audit concluded that this action was not justifiable.

Result: No action was taken. However, during the plant upgrade the pump station was replaced.

- Alternative C-1: In comparison to other extended aeration facilities the WWTP consumed a higher amount of energy (2.1 kilowatts) per pound of $\mathrm{BOD}_{5}$ stabilized. Additionally, the aeration process was found to consume more energy than any other plant component. It was recommended that a microprocessor-based process control system be installed. The system should be capable of process control, load management, preventive maintenance reporting, records management, and alarm monitoring. The process control should be based on the aeration basin dissolved oxygen (DO) content which should be monitored continually. The estimated installation cost was $\$ 31,500$ and the estimated annual savings $\$ 29,000$. The calculated payback was 1.1 years. The audit also proposed to operate only one of the two aeration basins and to operate process control according to mean cell residence time (MCRT). 
Result: A process control system was installed which monitored and controlled the aeration according to DO, low flow, and high flow conditions. One of the aeration basins was removed from service and is currently used for biosolids storage.

- $\quad$ Alternative C-2: The audit studied the feasibility of replacing the mechanical aerators with diffused aeration.

Result: The payback was more than 15 years and the energy audit concluded that the action was not justified.

BBC considers the process control system for automated aeration monitoring and control to be its most successful energy conservation mechanism. The control system automatically reduces the aeration basin DO content to the lowest level which will still achieve optimum wastewater stabilization. Other aspects of BBC's energy conservation program include:

- A time of use on-peak/off-peak load management system
- Upgrade of pump motors to high efficiency windings and low voltage starters

- Addition of recirculation to the influent pump station to achieve a constant electrical load

- $\quad$ Replacement of the mercury vapor lighting with sodium lighting

- Use of energy efficient windows in the operations building,

- $\quad$ Recent pump upgrades at two lift stations. 
A summary of the BBC electrical usage and cost before energy conservation is shown in the following table (taken from the original energy audit report).

\begin{tabular}{|c|c|c|c|}
\hline 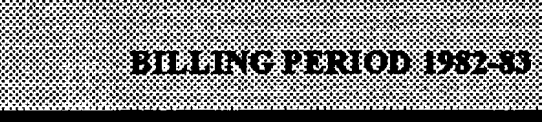 & 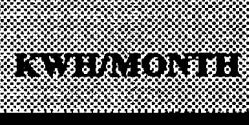 & 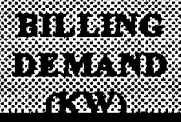 & 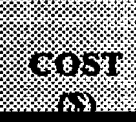 \\
\hline $198210 / 16-11 / 15$ & 180,000 & 618 & 9,772 \\
\hline $198211 / 16-12 / 15$ & 181,500 & 390 & 7,981 \\
\hline $198212 / 16-1 / 15$ & 160,750 & 380 & 6,278 \\
\hline $19831 / 16-2 / 15$ & 199,000 & 370 & 7,724 \\
\hline $19832 / 16-3 / 15$ & 191,000 & 385 & 7,569 \\
\hline $19833 / 16-4 / 15$ & 216,500 & 480 & $\mathbf{8 , 5 8 0}$ \\
\hline $19834 / 16-5 / 15$ & 218,000 & 480 & $\mathbf{8 , 8 4 0}$ \\
\hline $19835 / 16-6 / 15$ & 193,500 & 465 & 8,006 \\
\hline $19836 / 16-7 / 15$ & 205,500 & 460 & 8,636 \\
\hline $19837 / 16-8 / 15$ & 186,000 & 450 & 9,091 \\
\hline $19838 / 16-9 / 15$ & 184,000 & 430 & 8,900 \\
\hline $19839 / 16-10 / 15$ & 205,000 & 455 & 9,681 \\
\hline TOTALS & $2,321,250$ & 5,363 & $\$ 101,058$ \\
\hline 12 MONTH AVERAGE & 193,437 & 447 & 58,422 \\
\hline 2 YEAR AVERAGE & 197,812 & 454 & $\$ 8,755$ \\
\hline
\end{tabular}

Average power cost (based on kwh) $=\$ 0.04$

Average cost/MG treated $=\$ 117$

Average kwh/MG treated $=\$ 2695$

$\mathrm{Kwh} / \mathrm{b}$ BOD stabilized $=2.1$

The plant has also improved operators' skills through involvement with energy conservation equipment installation contractors. The involvement developed a working interest in the energy saving equipment and motivated the operators to become more energy-aware. 


\section{Description of the Technologies}

The process control system consists of an Andover controller unit which communicates with a laptop computer (386 microprocessor). The unit is accessible to the operational staff and chief operator. The microprocessor is connected to a modem which allows the chief operator to monitor and adjust parameters from his home. The system controls the extended aeration basin aerators according to DO, high flow, and low flow. DO information is obtained from a permanent self-cleaning, DO probe which is located toward the effluent end of the extended aeration basin. The facility staff anticipates that the probe will require replacement in the future at a cost of $\$ 1,200$ to $\$ 1,500$.

Target $\mathrm{DO}$ in the aeration basin is $1 \mathrm{mg} / \mathrm{L}$ to $4 \mathrm{mg} / \mathrm{L}$. Energy is conserved through reduced operation of the four 100 horsepower, low speed, mechanical aerators. Previously, the DO level was collected manually with less frequency which could result in excess aeration.

The system has an approximate five to ten minute delay which requires a stable DO before adjusting the aeration through control of the aerators. The delay is to eliminate short off/on cycles of the aerators. The delay is automatically overridden by the low DO mode as necessary to start additional aerators.

The plant staff conducts a manual check of the aeration process DO content three times daily at four locations in the basin. This manual collection of DO readings is with an independent meter to assure no malfunction of the controller system has occurred.

The system monitors flows from many locations in the wastewater plant. If the high flow exceeds a preset volume of approximately 8.0 MGD the final aerator in the aeration basin is shut off. This allows the mixed liquor suspended solids to settle out and be stored in the aeration basin during excess flows. This action conserves electricity and greatly reduces the effluent suspended solid level during high flow events. When the flow returns to normal the aerator is started and again suspends the solids. The flow control also has a delay to eliminate short cycle of the aerator. During low flows, if the process is stable, the process control system continues to operate from the DO input. However, the system alternates the aerators in service. Regular operation of all the aerators should extend their life.

Other major processes are also operated by the process control system. The system monitors the tertiary filters for flow rate to determine optimal timing for backwashing. The aerobic digester has two 100 horsepower mechanical aerators. Aeration was controlled by the process control system before the WWTP upgrade, but was not tied into the system after the upgrade. The biosolids storage basin is not automatically controlled by the process control system, however, following a manual start, the controller operates the four aerators as mixers. The process control system also can graph and print any variable, generate daily reports, and generate histories of variables. 
In response to the energy audit concern of inflow and infiltration-induced high flows, a sluice gate was installed to achieve flow equalization during rainfall events. The gate caused the excess flow volume to backup water in approximately four miles of the collection system. This reduced the surge and allowed a constant volume to be pumped during the storm event, which reduced the electrical consumption.

During the facility upgrade the sluice gate was removed and the influent pump station was modified. An Allen Bradley controller was added to the influent pump station. Also, an automatic "Beck" valve was installed to maintain a constant head, of approximately ten feet, in the influent pump wet well. The valve uses a sonic meter to detect the head in the influent wet well and then recirculates a variable volume of the flow back to the wet well. This allows the influent pumps to run continuously, in a steady state, and achieves a constant electrical pump load. It does not result in a reduced RAS pumping, reduced chlorine usage, or reduced aerobic digester supernatant pumping, as recommended in the study.

During the facility upgrade, many pump motors were replaced with motors which have high efficiency windings and low voltage starters. The Gasters Creek Pump Station pumps were replaced with high efficiency, higher capacity centrifugal pumps. The Little Buffalo Creek Pump Station pumps were replaced with high efficiency submersible pumps. The RAS screw pumps were replaced with centrifugal pumps. The original RAS pump station was then placed into service as the WAS pumping station. The screw pump belt drives, which experienced some slippage, were replaced with direct drive units to conserve energy. The plant also replaced the mercury vapor yard lighting with energy efficient sodium vapor lighting, and installed energy efficient windows in the operations building.

\section{Process Modifications}

The process control system has saved energy, improved the aeration process and reduced the effluent suspended solids. From October 1981 to October 1983 the annual average effluent parameters were $\mathrm{BOD}_{5}=12.5 \mathrm{mg} / \mathrm{L}, \mathrm{TSS}=26.5 \mathrm{mg} / \mathrm{L}$, $\mathrm{NH}_{3} \mathrm{~N}=0.72 \mathrm{mg} / \mathrm{L}$, and $\mathrm{DO}=8.2 \mathrm{mg} / \mathrm{L}$. Currently the annual average effluent parameters are $\mathrm{BOD}_{5}=8.23 \mathrm{mg} / \mathrm{L}, \mathrm{TSS}=$ $16.3 \mathrm{mg} / \mathrm{L}, \mathrm{NH}_{3} \mathrm{~N}=0.54 \mathrm{mg} / \mathrm{L}$, and $\mathrm{DO}=$ $7.13 \mathrm{mg} / \mathrm{L}$. This is likely the result of maintaining a uniform DO in the extended aeration basin, maintaining a DO which is optimum for stabilization, and retaining solids during high flows. The increased solids increased the loading to the aerobic digester by 15 to 25 percent.

Another process modification which has saved energy and improved the effluent quality is the removal of one aeration basin from service. The aeration basins were designed to treat $10 \mathrm{MGD}$, while the average flow was $4.56 \mathrm{MGD}$. Use of a single aeration basin allowed operators to match the flow volume with the design. The MCRT was reduced, which conserved energy through less pumping. This reduction should also improve the effluent suspended solids through a reduction of pin floc. 


\section{Financial Benefits}

$B B C$ staff found that actual installation costs for the implementation of the energy audit recommendations were close to estimated costs. Actual payback time for the process control system was less than the 1.1 years originally estimated.

An operating budget increase has been unnecessary over the past five years.
Staff believes that energy savings have contributed greatly to stable operating costs. The two-year average monthly electrical cost during $1982-83$ was $\$ 8,755$ (at $\$ 0.044$ per kilowatt hour). Monthly electrical costs averaging $\$ 4,200$ over the period July 1993 to April 1994 reflect the effects of energy conservation measures on electrical costs at the BBC plant. 


\section{Seattle Metro Renton Water Reclamation Plant}

\section{Facility Description}

Unlike the other wastewater treatment plants in this study, the Seattle Metro East Division Reclamation Plant at Renton does not use its biogas onsite for heating and/or cooling. Instead, Metro has worked out relationships with local utilities that have made it more costeffective to sell the gas for offsite use and replace its potential in-plant use with electrically operated heat pumps that remove heat from effluent. The economics that make this feasible depend on the low prices for electricity in the Seattle area, and grants and other assistance from the electric utility. Metro also has developed a unique program, called MetroTherm, which uses effluent for offsite heating and cooling of buildings at privately owned facilities.

The Renton plant treats about $66 \mathrm{MGD}$ of wastewater. The plant is undergoing expansion, due to be completed in 1996, which will increase its current design capacity of 72 MGD to 108 MGD. Plant processes consist of primary settling, aeration, secondary settling, chlorination, and dechlorination. Biosolids are treated in dissolved air flotation thickeners, followed by anaerobic digestion and belt filtration. In 1986, a 12-mile effluent pipeline to Puget Sound was completed. Pipeline construction included eight reuse taps spaced along its length (Figure 6). Effluent is discharged two miles offshore in $\mathbf{5 8 0}$ feet of water.

Seattle Metro has undertaken several energy conservation activities at its Renton plant, including insulating the digesters, recovering waste heat from blowers, using energy efficient motors and variable speed drives, and installing motion detectors to control lighting in conference rooms.

\section{Energy Recovery from Biogas}

The Renton plant's four anaerobic digesters generate 1.2 million standard cubic feet per day of biogas. The facility scrubs the biogas to remove carbon dioxide, and sells the resulting 99 percent pure methane to the local gas utility. Metro receives approximately $\$ 1,100$ per day for the scrubbed gas. The biogas potential for onsite heating use is replaced with four 600-horsepower electricallyoperated heat pumps. These heat pumps supply 135 degree water to a closed loop system that meets 90 percent of building heat requirements, and also maintains ten million gallons of biosolids in four digesters at 96 degrees. The cooler water that has passed through the heat exchangers is used in the gas scrubber unit to increase its efficiency. 
Residuals Use and Energy Conservation

Figure 6: Location of Renton's 12-mile effluent pipeline

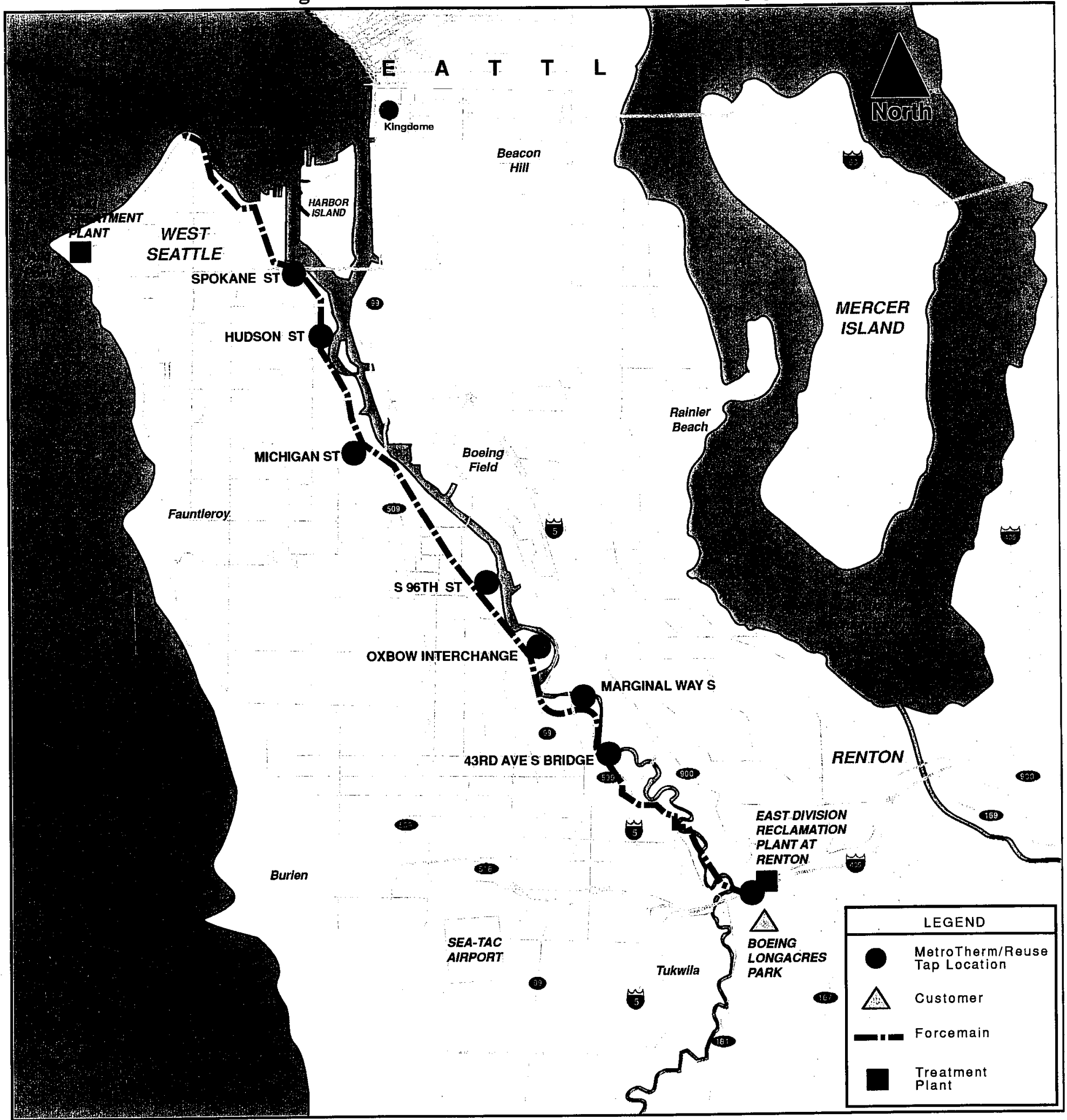


The heat pumps produce four times more heat than would be obtained per watt of power consumed by directly converting electricity to heat (3.4 Btus are obtained per watt hour). Metro anticipates that the efficiency will decrease when it changes from the current refrigerant (R12) to a new refrigerant (134A) that does not contain chlorofluorocarbons, because the 134A refrigerant is not as efficient in heat transfer.

\section{Advantage of Cold Water for Biogas Scrubbing}

The carbon dioxide scrubber consists of a vessel into which secondary effluent is injected under 300 psig. Digester gas is fed into the vessel, and during contact between the gas and the effluent, pressure forces the carbon dioxide into solution in the water. Cleaned methane gas is drawn off. To achieve maximum efficiency, cooled effluent that has passed through the heat pumps is used in the scrubber, since cooler water can hold more gas in solution.

The heat pumps drop the temperature of the effluent flowing through them by 10 degrees Fahrenheit at a flow rate of 960 gallons per minute. This chilled water is fed into the digester gas scrubber. Metro has found that savings can be achieved by operating a heat pump solely to produce chilled water to ensure that the digester gas is adequately cleaned to specifications. Without chilled water, summer heat conditions would cause reduced scrubber efficiency resulting in wasting some gas that does not meet sale specifications.

\section{The MetroTherm Program}

The plant's effluent is available for use in a unique program called MetroTherm. MetroTherm is designed to provide treated wastewater effluent for heating and cooling of buildings, both at the wastewater treatment plant and offsite at privately owned facilities. Taps in the effluent pipeline were placed to allow facilities to draw from and return effluent to the pipe.

In 1982, the State of Washington began a "District Heating and Cooling" (DHC) program to encourage communities to develop centralized hot water production to serve various energy needs. The Washington State Energy Office (WSEO) implements this program to provide project guidance, marketing support and funding sources for development of centralized energy. WSEO has provided grants and assistance and will continue to provide support to Metro with a $\$ 25,000$ grant and $\$ 25,000$ in services in 1994. Metro also received grants from the Bonneville Power Administration (BPA), which provided funding for initial feasibility studies that determined placement for the effluent pipeline taps.

Facilities can use effluent in three modes: heating and cooling, cooling only, or heating only, depending on individual customer needs and efficiencies associated with each site. A heat pump or heat exchanger and a compatible heating or cooling system is necessary to use the effluent (see Figures 7-9). The connection between the effluent and the facility occurs indirectly, through a heat 
exchanger, so there is no possibility of adding pollutants to the effluent. Metro's intention is that heat exchangers will be owned and operated by each participating facility.

The economics of using MetroTherm generally will favor new construction having large and continuous heating and cooling requirements and located near the effluent pipeline. Seattle Metro has entered into a demonstration project with The Boeing Company that will provide effluent for cooling Boeing's new training facilities located near the Renton plant. Eventually, Metro envisions some facilities taking heat from the pipeline and others returning heat to the effluent, yielding an unlimited potential for energy reclamation.

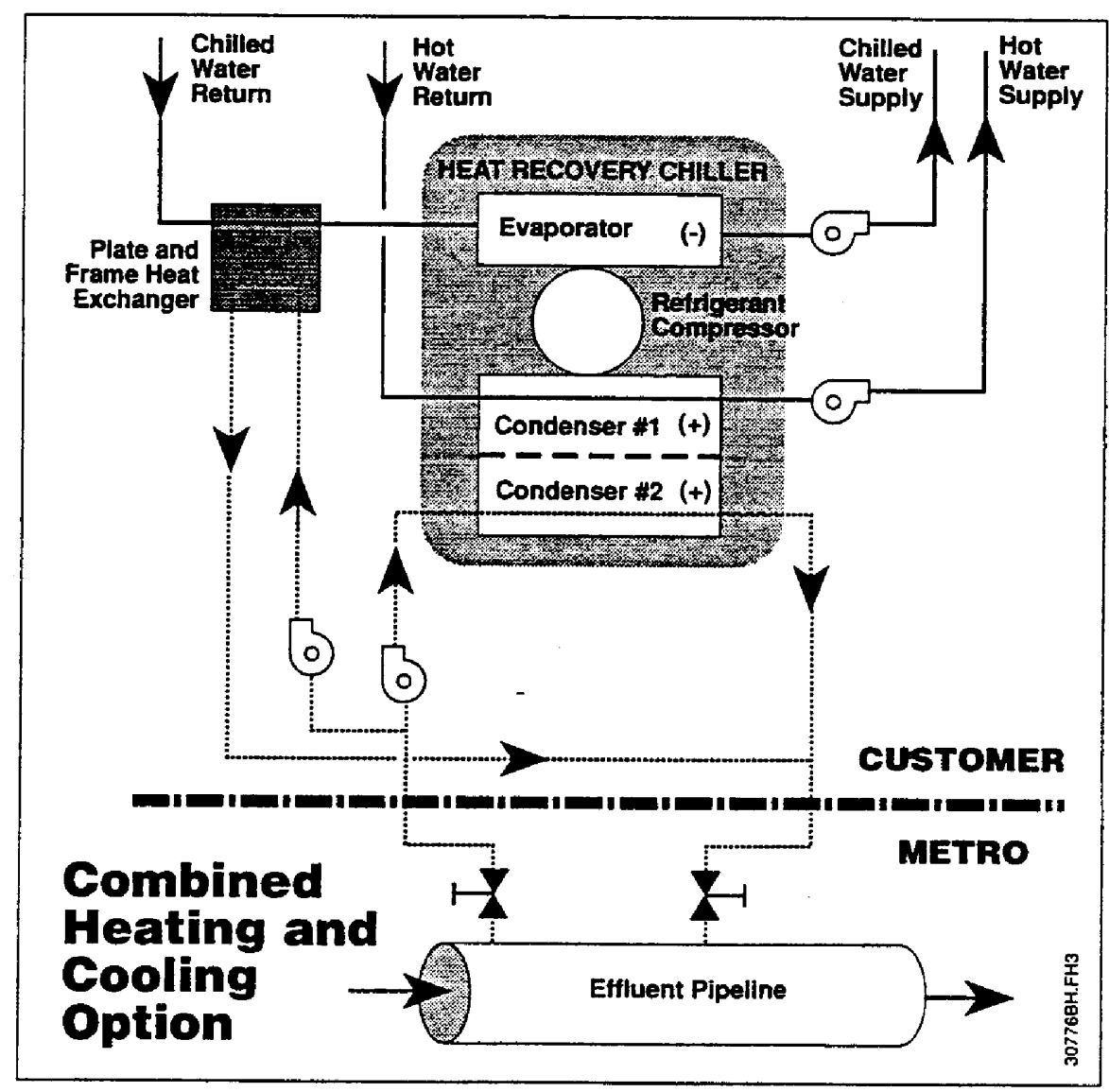

Figure 7: Combined heating and cooling option 
Residuals Use and Energy Conservation

Figure 8: Heating only option
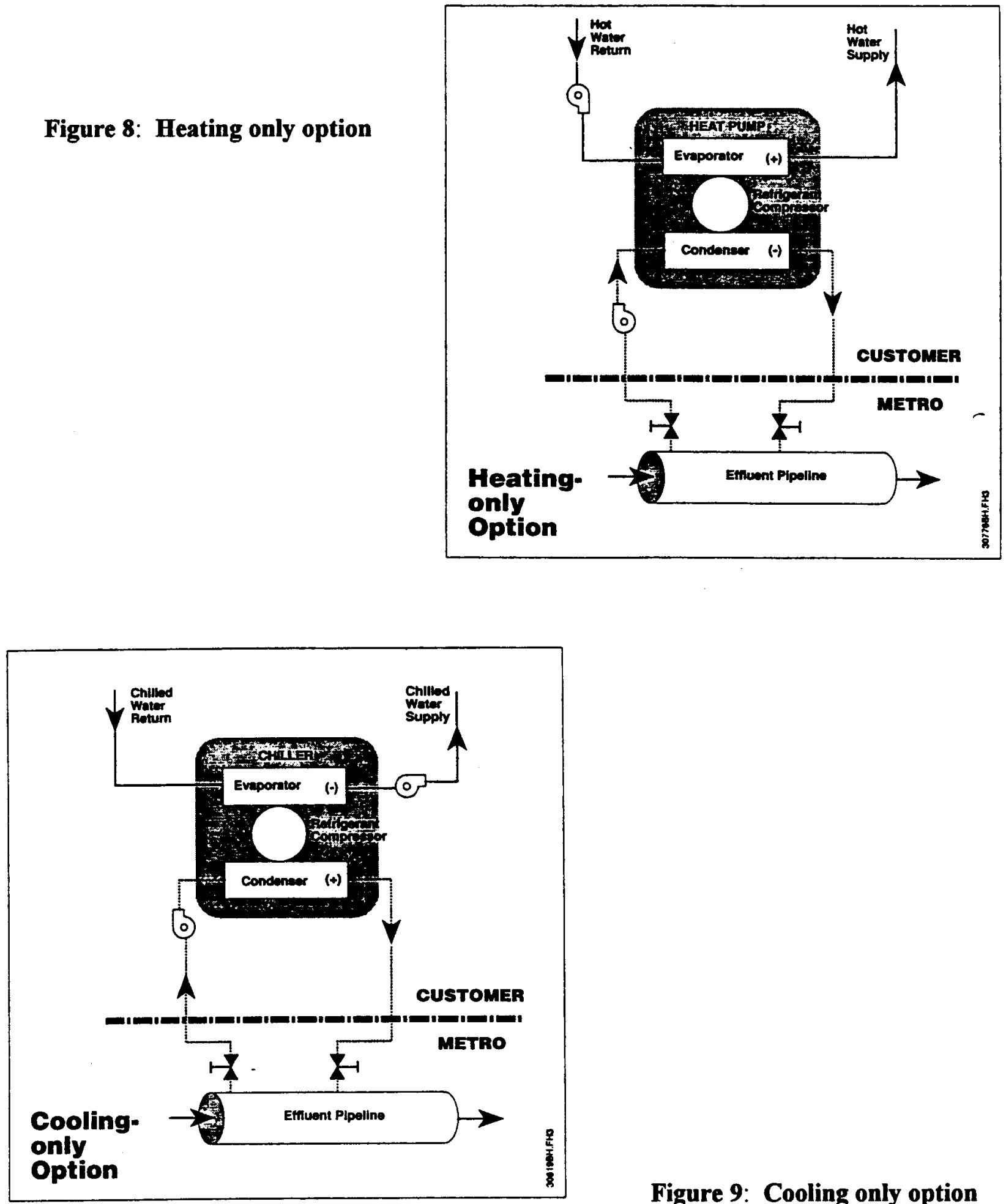

Figure 9: Cooling only option 


\section{The Boeing Company Project}

The Boeing Company is constructing a Customer Services Training Center near the Renton wastewater treatment plant, and is participating in a demonstration project with Seattle Metro to use effluent from the Renton plant to cool its facilities. During the demonstration period, both conventional cooling (via cooling towers) and MetroTherm cooling will be used. Boeing will operate these two systems simultaneously to collect data on performance and costs. The demonstration project was designed to commence in August 1994. Boeing makes a good subject for the demonstration project in part because it is incorporating MetroTherm cooling into new construction, where it is most costeffective to install, and because the Boeing training center will operate 24 hours per day. As a continuous operation, the center's cooling needs are also continuous, but peak period electricity costs are reduced through use of MetroTherm.

Boeing received a $\$ 1.2$ million grant from Puget Sound Power and Light Company to participate in the demonstration program. Although costs and savings that will result from use of the MetroTherm facilities will not be fully known until completion of the demonstration program, Boeing expects to achieve benefits in several other areas. Thus, an aesthetic benefit will result from use of MetroTherm, as Boeing can avoid building and operating additional cooling towers on the site. This will conserve potable water. In addition, pollution prevention benefits will be realized in that chemicals will not be necessary for cooling towers and boilers.

\section{Applicability to Other Systems}

Use of effluent for onsite heating and cooling purposes could be economically feasible for many wastewater treatment plants. Facilities that do not use anaerobic biosolids digestion and thus have no onsite fuel production could use effluent heat pumps for building heating and cooling requirements.

Seattle Metro is unique in the siting of its effluent pipeline. However, more WWTPs are building pipelines as part of water reclamation projects. These pipelines could be designed for the dual purpose of water reclamation and energy reclamation. Industries located near treatment plants should also be able to take advantage of effluent heating and cooling. Areas having high electricity costs would provide a more favorable environment for such opportunities, due to the higher financial incentive.

\section{Financial Benefits of the Energy Conservation Program}

Metro received a $\$ 400,000$ grant from Puget Sound Power and Light Company to defray nearly half the $\$ 900,000$ (1987 dollars) cost of the heat pumps. The capital costs have been recovered through Metro's sewer rates and bonds.

In 1992, the heat pumps operated for a total of 9,200 hours. The electricity cost (at 2.5 to 3 cents per kilowatt hour) was 
approximately $\$ 105,000$. The cost of maintenance on the four heat pumps totaled $\$ 30,000$ for the year. The total heat production was 55 trillion Btus. The following table summarizes this information, and contrasts it with the sale price $(\$ 410,000)$ and Btu value of the digester gas.

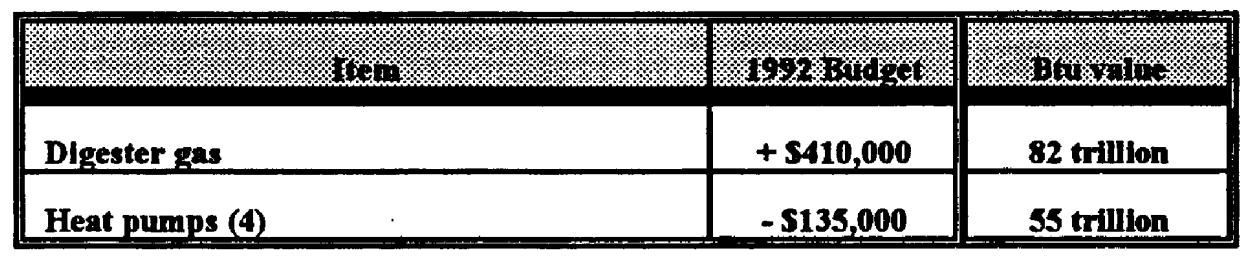

By selling the digester gas and replacing its potential onsite heating use with electrically operated heat pumps, the facility realizes a gain of $\$ 275,000$.

\section{Benefits of the Energy Conservation Program: Regulatory Compliance}

Metro's energy conservation activities have positive environmental benefits. By not burning biogas onsite, Metro avoids creating air emissions from such a process. In addition, to the extent that companies use heat exchangers rather than natural gas for heating purposes, additional reduced emissions would be expected. No effect on effluent quality has been observed because of the MetroTherm program. 


\section{Other Promising Technologies}

\section{Anaerobic Wastewater Treatment}

Anaerobic wastewater treatment is sometimes called "upflow anaerobic sludge blanket" (UASB) or as anaerobic upflow ("ANFLOW"). The ANFLOW process has been successfully proved for treatment of domestic wastewater at WWTPs in Oak Ridge and Knoxville, Tennessee, in pilot studies conducted by Oak Ridge National Laboratory and the cities (funded by the Department of Energy). Anaerobic wastewater treatment is most often used as a pretreatment process, with effluent being directed into a conventional aerated treatment process such as activated sludge or trickling filtration for polishing. This technology is most appropriate for WWTPs receiving less than 1 MGD and for pretreatment of high-strength industrial wastestreams.

In the anaerobic upflow process, wastewater influent is drawn off the inlet of the primary clarifier and directed into a bioreactor. In the ANFLOW system, the bioreactor is a 24,000-gallon cone-bottom tank that contains a plastic or ceramic filter medium. The UASB process uses a sludge blanket instead of a constructed filter, and tanks are sized as necessary. Wastewater enters near the bottom of the bioreactor and flows upward through the filter medium. Effluent is discharged near the top of the bioreactor and sludge can be removed from the bottom. Bacteria on the filter or in the sludge blanket consume the organic material in the wastewater, producing methane gas that bubbles to the top and is collected. Bioreactor effluent typically receives additional treatment to meet surface water discharge standards, although effluent from some industrial facilities that discharge to WWTPs may not require additional treatment.

In the early 1980's, Anheuser Busch began developmental work on this technology, which was not widely used then for treatment of food processing wastewater. Brewery wastewater is readily biodegradable and free of toxics, but its BOD/COD content is very high. In 1991, Anheuser-Busch modified existing aerobic wastewater treatment processes to incorporate UASB at breweries in Jacksonville, Florida and Baldwinsville, New York. These facilities generate wastewater with highly variable flow, BOD and solids loadings, $\mathrm{pH}$, and temperature. Therefore, screening, equalization and $\mathrm{pH}$ and temperature control are necessary to reduce the impact on the UASB process. Ferric chloride is added to the reactors to control odors.

Anaerobic wastewater treatment has many advantages over aerobic treatment. Estimates based on data from the 
Tennessee pilot study indicate that an ANFLOW system would use approximately $\mathbf{4 5}$ percent of the energy required by an activated sludge system for a design flow of 50,000 gallons per day, and would use approximately 30 percent of the energy required by a 1 MGD activated sludge plant. Anheuser-Busch reports a 75 percent reduction in energy consumption with the UASB process online. UASB reduces energy consumption because anaerobic treatment requires less energy than aerobic treatment and produces energy through methane generation.

Methane recovery from gases collected in the bioreactor's vapor space is 70 to 75 percent. This compares very favorably to methane recovery from anaerobic digesters, which typically produce only 55 to 60 percent.

Anaerobic wastewater treatment produces relatively small amounts of biosolids, reducing the costs and energy requirements associated with their disposal. The ANFLOW pilot plant produced only about 25 percent of the solids that would be produced by an activated sludge process.

Anaerobic treatment produces gases which consist mostly of methane. The methane is captured and used to replace nonrenewable fuels. In contrast, activated sludge and other aerobic processes produce only carbon dioxide gas, which is vented to the atmosphere and contributes to the potential for global warming. Anheuser-Busch calculates that an anaerobic process treating
100,000 pounds of BOD per day would produce 40 percent less $\mathrm{CO}_{2}$ than an aerobic process. This works out to a reduction of 14,000 tons of $\mathrm{CO}_{2}$ per year.

Nutrient addition is frequently required for aerobic treatment of high-strength food processing wastestreams because typically such wastestreams do not contain nitrates and phosphates adequate to support the biological growth necessary to consume the BOD load. Anheuser-Busch found that nutrient addition was not necessary for UASB treatment, which produces less biomass growth and thus has a lower nutrient requirement than aerobic treatment.

Finally, Anheuser-Busch has shown that treatment costs are considerably lower with the UASB process. Before installing UASB, the cost to treat this wastestream was $\$ 0.076$ per pound of BOD. With the anaerobic process, costs dropped to $\$ 0.019$ per pound. Costs savings were realized in residuals handling, reduced need for aerobic treatment, and through biogas recovery. Construction costs are about half as great.

The DOE-funded ANFLOW study concluded that ANFLOW is more energyefficient than conventional aerobic processes, and can be a net energy producer. Depending on what associated processes are required to meet effluent discharge limits and depending on costs of biosolids disposal, it is possible that an ANFLOW secondary treatment plant might approach energy independence. Although the most optimal operating 
temperature range for methanogenic organisms is 85 to $100^{\circ} \mathrm{F}$, ANFLOW could operate effectively at temperatures as low as $70^{\circ}$. Influent of lower temperature would probably need to be adjusted, however.

\section{Lake County Southeast Geysers Effluent Pipeline Project}

About 30 years ago the large California utility, Pacific Gas and Electric

(PG\&E), opened a geothermal energy plant in Lake County, California. This facility, known as the Geysers, is the nation's largest geothermal resource area, with over 1,000 MW of installed power plant capacity. However, since the mid-1980's, production from the Geysers has been declining at a rate of about 6 percent annually, due to the declining amount of natural steam. rock." enhanced environmental protection resulting from a more desirable means of wastewater disposal, and retention and creation of jobs in the community.

The project is the world's first system that will convert wastewater effluent into geothermal steam, and, in turn, electricity for community residents and businesses. It is also unique in the public/private

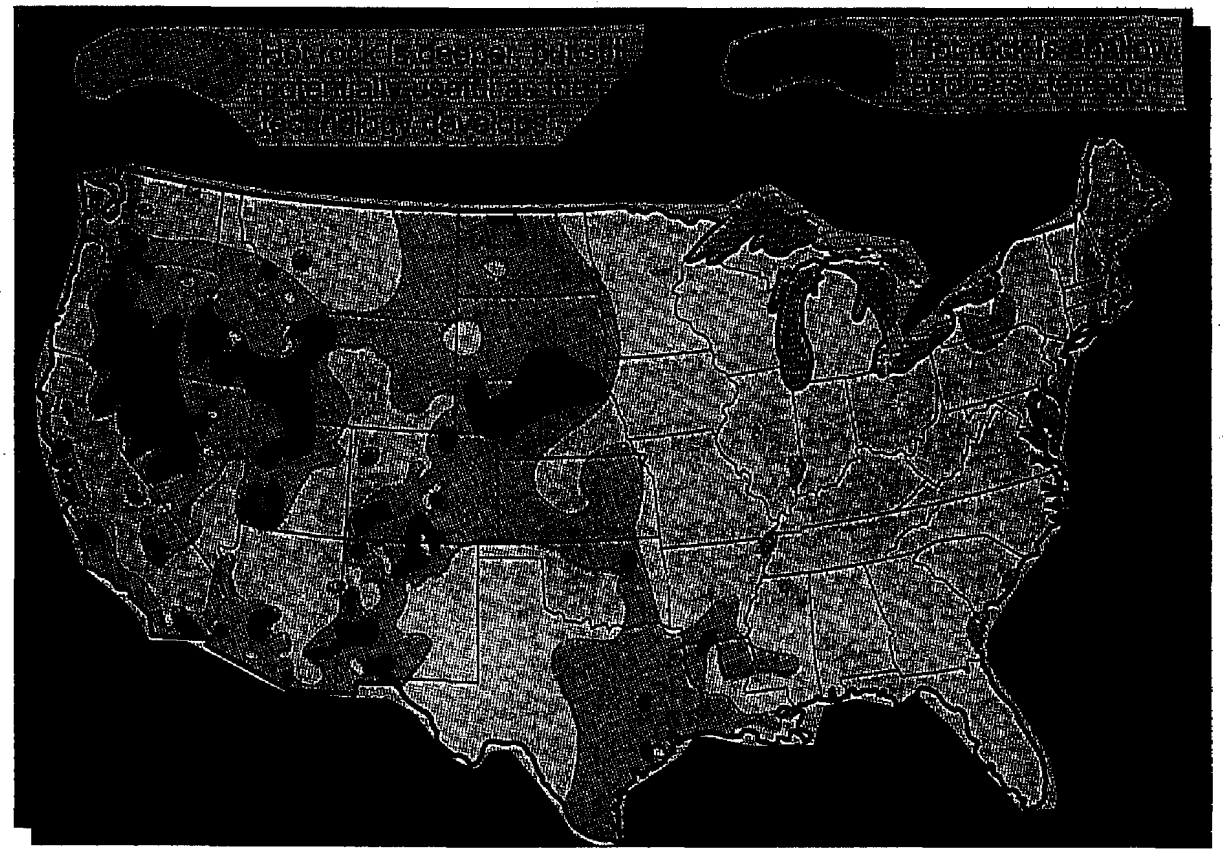

Figure 10: Locations of geological formations containing "hot

Source: San Jose Mercury News
Lake County designed an effluent pipeline project to partially remedy the problem by supplying treated wastewater effluent for injection into the steam reservoir, thereby augmenting naturally-occurring steam extracted for power generation. The project is expected to produce three major benefits: sustainment of geothermal generation, partnership created for its implementation. Besides Lake County, participants include PG\&E, Northern California Power Agency (a consortium of twelve municipal electric utilities), Calpine Corporation (a geothermal development company), the California Energy Commission, and the U.S. 
Departments of Energy and Interior.

These participants are sharing in the $\$ 40$ million construction cost of the project. This cost includes associated wastewater treatment plant improvements.

Although the southeast Geysers project is the first in the nation, large parts of the western United States have been found to contain geologic formations of shallow hot rock (Figure 10). These areas have potential for development as geothermal energy sources. WWTPs are located in population centers which could use the energy that would be obtained through injection of wastewater effluent and recovery of steam.

The southeast Geysers project will consist of a 26-mile, 24-inch diameter buried pipeline that will carry 7.8 MGD of secondary-treated effluent from two Lake County WWTPs to the Geysers geothermal steamfield. The effluent will be injected to a depth of approximately 7,000 feet. Pipeline operation and maintenance is estimated at $\$ 2$ million annually.

Depending on steam recovery rates for the injected effluent, the project is expected to produce an additicnal $70 \mathrm{MW}$ of generating capacity for existing geothermal power plants at the Geysers. This will equate to as much as $\mathbf{8 2 5 , 0 0 0}$ megawatt-hours of clean, lowcost energy annually. Construction should commence in early 1995, with the project becoming operational in 1996.

\section{Biomass-Enhanced Digester Gas Production}

Several WWTPs in California have successfully augmented production of biogas by adding biomass directly to the anaerobic digesters.

South Bayside System Authority (SBSA), operates a tertiary WWTP in Redwood City. In 1986, SBSA began a demonstration program to find out the effects of adding plant scum and grease trap wastes to one of its two digesters. The scum and grease wastes were added only to Digester 1, while Digester 2 was maintained as a control. Both digesters continued to receive the same volumes of solids from the gravity thickener. SBSA kept records on the volume of wastes received and the amount of gas generated, and also various operating conditions of each digester.

SBSA found that excellent digester mixing (turnover rate $=8.5$ times daily) and long detention times (40 days) probably contribute to the ability to accept large volumes of grease. Grease loadings were increased as the demonstration project progressed, reaching 730,215 gallons per year in 1993 for Digester 1. SBSA believes that this figure does not represent the maximum loading for the digester. SBSA calculated that each gallon of grease introduced to the digester results in the production of about 20 cubic feet of biogas. When the digesters were cleaned, no significant difference was found in the contents of the control versus the digester that received grease wastes. 
SBSA now accepts grease trap wastes and septic wastes from a large geographic area beyond its service area. This program provides an environmentally beneficial disposal option for waste haulers. Instead of conventional disposal into a designated area of the collection system, these wastes are placed directly into an anaerobic digester. By avoiding the secondary treatment process, none of the energy inherent in the wastes is lost and there is no chance of adversely affecting the secondary process. No effects on effluent quality have been observed because of the demonstration project. 


\section{Factors that Contribute to Success}

The facilities in these case studies have been highly successful in carrying out various types of energy conservation activities. Orange County Sanitation Districts, Hyperion, and Sanford's Big Buffalo Creek WWTP analyzed the factors that have contributed to the success of their programs. Facilities considering implementing similar energy programs should benefit from reviewing the factors that go into the achievement of a successful program.

The facilities in these case studies identified the primary factors that have contributed to their success as follows:

1) The design of CSDOC's two adjacent wastewater treatment plants provides considerable flexibility in treatment options. For instance, operators can divert flow from Plant 1 to Plant 2. Secondary treatment is flow equalized, and can be adjusted to maximize treatment. Advanced primary treatment allows solids removal to be maximized in the primary clarifiers, reducing the loading to secondary processes and giving the plants greater effective capacity. This allows experimentation with energy conservation activities without risking NPDES or air permit noncompliance.

The design and operating criteria at
Sanford's Big Buffalo Creek WWTP also provide for flexibility. The parallel design of the extended aeration basins allows easy removal of one basin from service and matching of average daily flow to the basin design volume. This alleviates underloading and subsequent sludge aging and pin floc which can cause deterioration of secondary clarifiers effluent. The process control system allows operators to be instantly aware of factors which affect the wastewater treatment process. The system's automatic response achieves optimum treatment in the most energy efficient manner. The ability to equalize the flow through the automatic valve at the influent pump station eliminates pump cycling and reduces the electrical demand. This equalization creates a steady state in the extended aeration process, which improves treatment.

2) CSDOC and Sanford cite their effective programs to control incoming pollutants. CSDOC was one of the first facilities in California to establish loadingbased limits for industrial users for both toxics and conventional pollutants.

Industrial users are limited to discharging 10,000 pounds of BOD per day each. At present, CSDOC is studying the feasibility of having industrial users convert soluble BOD to solids before discharge to the sewer. Lower BOD loads to the plant mean lower treatment costs. 
3) Hyperion identified staff expertise as most important to the success of their energy recovery operations. The HERS system is the most technically complex of the facilities in these case studies. Hyperion has assembled a diverse and competent staff whose backgrounds and training are in power generation. Additional support is provided by the trained plant operators and instrumentation staff whose primary responsibilities are in wastewater treatment.

CSDOC and Sanford also identified the importance of management and staff training, interest, and technical expertise to successfully carry out energy conservation without risking noncompliance with permit requirements.
Their staffs have a genuine interest in energy saving actions in addition to expertise in wastewater operations.

4) Although CSDOC is a public agency, it is operated similarly to a business enterprise with managers having certain goals to achieve in cost savings and other areas. This management attitude provides a strong motivation for energy conservation.

5) Sanford cites the value of a comprehensive energy audit as an essential tool for cost-effective energy conservation. 


\section{The Influence of Financial Factors}

The wastewater treatment plants included in this study provide several good examples of the factors that should be considered in making decisions regarding the use of biogas and other renewable energy technologies.

\section{Biosolids: Onsite Use versus Offsite Reuse}

Unlike the other facilities in this study, Hyperion recovers energy from biosolids by drying and oxidizing the digested solids. This activity augments Hyperion's total electricity generation by 20 percent. At present, the cost to prepare the biosolids for burning is greater than the value of the electricity subsequently generated by using the biosolids for energy.

However, under other scenarios the cost balance changes to favor onsite processing of biosolids, as follows:

1) If the cost of electricity purchased from the public power company were to increase by 45 percent or more, the onsite option becomes more economical.

2) If the cost to dispose of biosolids offsite were to at least double, it becomes more cost effective to process the biosolids onsite.
3) Recent estimates by Hyperion staff show that the addition of steam dryers lowers the cost of onsite biosolids processing to $\$ 109$ per dry ton, compared to $\$ 132$ for offsite management.

\section{Biogas: Onsite Use versus Offsite Sale}

Biogas is typically used onsite by wastewater treatment plants in one or both of two ways: 1) to generate electricity, and 2) to provide heat for digesters and buildings. The low cost for electrical power in the Seattle area means that using biogas to generate electricity is not particularly attractive. The Renton plant obtains electricity at an average cost of about $\$ 0.025$ per kilowatt hour. In comparison, electrical costs for WWTPs in Southern California average $\$ 0.08$ per kilowatt hour. Thus, the payback period for installation of engine generators that use biogas as fuel would be about three times longer in the Seattle area, or around 20 years.

The other potential for in-plant use of biogas is to generate heat for facilities and for the anaerobic digesters. Metro has replaced biogas for this use with the electrically operated heat pumps. A grant was received to defray about half the purchase cost of the heat pumps, and this contributed to the attractiveness of this 
option. At electricity costs about three times Metro's (that is, about 7.5 cents per kilowatt hour), the cost of replacing biogas with heat pump technology is probably about even in terms of operating and maintenance costs, all other factors being equal. If the initial purchase cost of the heat pumps must be borne by the facility, as opposed to receiving a grant or subsidy, the benefit decreases further.

Metro's low electricity costs result in a low operating cost for heat pumps. Treatment plants capable of producing biogas should consider the capital and operation costs for engine generators that can use biogas as fuel versus the capital and operating costs of heat pumps. Other WWTPs may not be subject to the conditions which favor Metro's use of heat pumps.

Facilities located in areas where they pay more than approximately 7.5 cents per kilowatt hour may find that using digester gas onsite is the more cost-effective option. A WWTP considering the choice of using the gas onsite versus selling it to a utility might select a different option.

For instance, depending on the circumstances, it might be more cost effective to use part of the biogas production for onsite heating. The remainder would be available for sale at (with all other factors being equal) about 33 percent of the income that would be received from sale of all the gas. This option would avoid the capital cost and operation and maintenance costs for heat pumps.

\section{Energy from Effluent: Purchase versus Contractual Equipment}

Seattle Metro's MetroTherm program is currently based on the premise that heat exchangers will be owned and operated by each participating business that uses effluent for heating or cooling purposes. Another option for such energy recovery programs would be for the WWTP or an outside party to provide, operate, and maintain the heat exchangers, perhaps on a rental or contractual basis.

This would address three concerns from a potential customer's viewpoint:

- The customer may have no expertise in the operation or maintenance of heat exchangers;

- The customer may not want to or be able to bear the capital costs of purchasing a heat exchanger unit;

- The customer may not wish to commit to purchase of a heat exchanger system without knowing how well it will work for his particular needs.

By providing a second option to potential customers, one not involving outright purchase and operation of the heat exchanger units, the WWTP could attract businesses who otherwise may not have considered using the effluent energy recovery program. 


\section{Conclusions}

These case studies show that many options for energy recovery or conservation are available for wastewater treatment plants. The options selected by a particular plant should be based on sitespecific considerations, and these will vary from facility to facility.

Some options are in more widespread use than others. For instance, energy recovery from biogas is universally cost effective and has gained widespread acceptance. The technology exists to allow full use of biogas, and the extra costs of incorporating this energy source into a system are small. The payback period for installation of biogas energy recovery at plants having anaerobic digesters is short, typically less than six years. Recovery and use of biogas accomplish energy conservation and pollution prevention goals, and also cost savings, making this an obvious choice for application in all treatment plants that employ anaerobic digestion for stabilization of wastewater biosolids.

Other energy conservation and municipal pollution prevention activities can be integrated with use of biogas, as demonstrated by the Sunnyvale WPCP, including collection and use of landfill gas, recovery of waste heat, water reclamation, and municipal water conservation. Often, wastewater treatment plants are located near municipal landfills, and could potentially develop the landfill gas as an additional energy source. Advantages lie not only in the cost savings from energy recovery from the landfill gas, but also in meeting regulatory and safety concerns posed by landfill gas emissions.

Energy conservation is considered a worthwhile goal because it conserves natural resources. The examples of CSDOC and Hyperion suggest that reductions in energy use can also lead to increased ability to comply with air emissions regulations. Carbon dioxide is a "greenhouse gas" which is released by all wastewater treatment and biosolids management processes. Converting biosolids to fuel achieves substantial benefit from the wastes before carbon dioxide is ultimately released. In addition, nonrenewable energy sources are replaced by renewable energy from wastewater.

The experiences of these facilities show that actions which enhance process efficiency, such as advanced primary treatment, can simultaneously result in increased energy recovery. There is no evidence that energy conservation efforts have in any way adversely affected receiving water quality. 
The energy conservation potential of effluent heating and cooling has been explored to date by only a few facilities. However, with more plants incorporating water reclamation, leading to pipeline construction through commercial and residential areas, potential opportunities for application of this technology are increasing. Water reclamation projects should be designed not only to reclaim water as a valuable resource, but also to take advantage of any opportunities to substitute effluent heating and/or cooling for nonrenewable energy sources. 


\section{Resources}

Pierson, F.W. and C.V. Pearson. 1982. Energy from municipal waste:

Assessment of energy conservation and recovery in municipal wastewater treatment. Argonne National Laboratory, Argonne, II. NTIS No. DE85-004826.

Miller, Williams \& Works. 1984. Energy Audit: Buffalo Creek Wastewater Treatment Facility, City of Sanford, NC. Prepared for the North Carolina Department of Commerce, Energy Division.

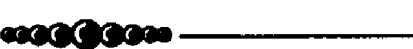

The Washington State Energy Office has literature and computer programs available pertaining to district heating. WSEO can be contacted at the following address:
Washington State Energy Office District Heating and Cooling Program 809 Legion Way S.E. Olympia, Washington 98504 (206) 586-5000

Seattle Metro can provide information regarding the MetroTherm Program, and can be contacted as follows:

MetroTherm Program Water Pollution Control Department, M.S. 130

821 Second Avenue

Seattle, WA 98104

(206) 689-3184

Additional information on use of geothermal energy is available as follows:

Mark Dellinger Energy and Resource Manager Lake County Sanitation District Lakeport, CA

(707) 263-2273 


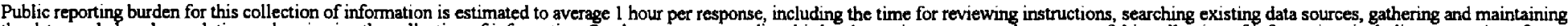

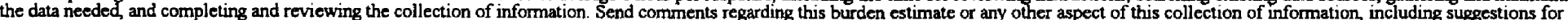

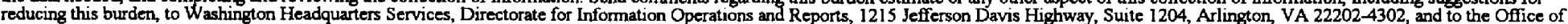
Management and Budget, Paperwork Reduction Project (0704-0188), Washington, DC 20503

\begin{tabular}{l|l|l} 
1. AGENCY USE ONLY (Leave & 2. REPORT DATE & 3. REPORT TYPE AND DATES COVERED \\
blank)
\end{tabular}

June 1995

Final subcontract report

\section{TITLE AND SUBTITLE}

Case Studies in Residual Use and Energy Conservation at Wastewater Treatment Plants

Final Report

\section{AUTHOR(S) \\ Dianne Stewart}

\section{PERFORMING ORGANIZATION NAME(S) AND ADDRESS(ES)}

Science Applications International Corporation

5150 El Camion Real

Los Altos, California 94022

\section{SPONSORING/MONITORING AGENCY NAME(S) AND ADDRESS(ES)}

National Renewable Energy Laboratory

1617 Cole Boulevard

Golden, CO 80401-3393

\section{FUNDING NUMBERS}

(C) YAE-3-13480-1

(TA)WM51.1010

\section{PERFORMING}

ORGANIZATION

REPORT NUMBER

DE95009216

10.

SPONSORING/MONITORING

AGENCY REPORT

NUMBER

NREL/TP-430-7974

\section{SUPPLEMENTARY NOTES}

12a. DISTRIBUTION/AVAILABILITY STATEMENT

National Technical Information Service

U.S. Department of Commerce

5285 Port Royal Road

Springfield, VA 22161 12b. DISTRIBUTION CODE

UC-1414

\section{ABSTRACT (Maximum 200 words)}

By integrating wastewater treatment with energy conservation, the waste water treatment plants described in this report have met the challenges of new environmental regulations. These facilities have achieved benefits in cost savings while enhancing their ability to comply with regulations. Their activities illustrate highly effective pollution prevention strategies.

\section{SUBJECT TERMS}

wastewater treatment plants, effluent, heating and cooling, pollution prevention
15. NUMBER OF PAGES

60 pages

16. PRICE CODE $\mathrm{A} 03$

\section{LIMITATION OF} ABSTRACT
17. SECURITY

CLASSIFICATION

OF REPORT

Unclassified
18. SECURITY

CLASSIFICATION

OF THIS PAGE
19. SECURITY

CLASSIFICATION OF ABSTRACT

\begin{tabular}{|l|l|l|l|}
\hline & & & \\
\hline & & & \\
\hline & & & \\
\hline & & & \\
\hline
\end{tabular}

